\title{
Product market competition and gender discrimination*
}

\author{
Dudley Cooke ${ }^{\dagger}$ \\ University of Exeter
}

\author{
Ana P. Fernandes ${ }^{\ddagger}$ \\ University of Exeter
}

\author{
Priscila Ferreira ${ }^{\S}$ \\ University of Minho, NIMA
}

October 2018

\begin{abstract}
This paper presents novel empirical evidence for the prediction from Becker's (1957) famous theory, that competition drives discrimination out of the market. We use a comprehensive business registration reform in Portugal as a quasi-natural experiment to study the effect of increased product market competition on gender discrimination. We use employeremployee data for the universe of private sector firms and workers, and exploit the staggered implementation of the reform across municipalities for identification. Increased competition following the reform increases growth of the female employment share and reduces the gender pay gap for middle-managers and for medium- and high-skilled workers but not for top-managers or the unskilled. We also find that discriminatory employers, approximated by a low female employment share, are more likely to exit and those that survive reduce overall employment growth following the reform, while non-discriminatory employers grow faster. Existing evidence has shown that gender discrimination reduces output; our findings suggest that entry deregulation can contribute to reduce inefficiencies arising from gender discrimination.
\end{abstract}

Key Words: Business registration reform, Discrimination, Entry, Gender Pay Gap, Product Market Competition, Wage Structure.

JEL Classification Numbers: J16, J31, J71.

\footnotetext{
*The authors are grateful to two anonymous referees for valuable comments that contributed to improve the paper. They also thank seminar participants at Bristol, participants at the ESPE 2018 conference and at the GEE/Nova Lisbon Competition conference for suggestions. Data access from the Portuguese Ministry of Labor and Social Solidarity and the Office for National Statistics (INE) are gratefully acknowledged. The research was partially funded by COMPETE (POCI-01-0145-FEDER-006683), the FCT/MEC, and ERDF through COMPETE 2020.

${ }^{\dagger}$ Email: d.cooke@exeter.ac.uk

${ }^{\ddagger}$ Corresponding author. Email: a.p.o.fernandes@exeter.ac.uk

§Email: priscila@eeg.uminho.pt
} 


\section{Introduction}

Women earn lower wages than men in all economies, including northern European nations such as Sweden and Norway, which are among the least discriminatory countries. ${ }^{1}$ An extensive body of empirical research has documented the wage gap between men and women. ${ }^{2}$ Although the gender wage gap has narrowed in recent decades, the difference in average wages has been very persistent. Gender discrimination creates inefficiencies that contribute to significantly reduce output across countries (see, e.g., Cavalcanti and Tavares, 2016; Cuberes and Teignier, 2016). Therefore, finding appropriate policies to respond to gender discrimination is important. In this paper, we study how entry deregulation, and the resulting increase in product market competition, contributes to reduce gender discrimination.

Our empirical analysis is framed by Becker's (1957) classical theory of employer discrimination, in which personal prejudice is the source of discrimination. The existence of a residual gender wage gap between workers performing the same tasks with the same skills, experience and educational level has been interpreted as reflecting discrimination. That interpretation is consistent with Becker's model. Gender-biased employers have a preference for male workers even if their wages are higher than those of females with the same productivity. This gives rise to segregation of workers across employers and to a gender wage gap. ${ }^{3}$ Becker (1957) argues that as discrimination increases costs, it is hard to sustain in a competitive market. An implication of Becker's (1957) model is that increased product market competition will reduce discrimination. This can happen as competitive pressure forces discriminatory employers, who have relatively lower profits, to exit the market, reduce growth, or give up their discriminatory behavior. As a result, demand for female workers should increase and the gender pay gap decrease.

This paper investigates the dynamic implication from Becker (1957), that changes in competition will reduce employer discrimination. We exploit a comprehensive business registration reform across industries in Portugal - the "On the Spot Firm" program - as a quasi-natural experiment to investigate whether increased product market competition reduces gender discrimination. We use linked employer-employee data for the universe of private sector firms and workers to investigate empirically how the reform affects the relationship between discrimination and firm survival and growth, as well as growth in the share of female employees and the gender wage gap. We estimate the effect of the reform on the gender pay gap for workers with different skill levels and across the corporate hierarchy.

The "On the Spot Firm" program was implemented from 2005 with the aim of reducing

\footnotetext{
${ }^{1}$ Hausmann et al. (2006).

${ }^{2}$ See, for example, Bayard et al. (2003) for evidence on the U.S. labor market; Albrecht et al. (2003) for Sweden; Arulampalam et al. (2003) for eleven European countries; Kawaguchi (2007) for Japan; among many others.

${ }^{3}$ Borjas and Ramey (1995), Hellerstein, et al. (2002) and Black and Brainerd (2004) provide more detailed discussions of Becker's (1957) model.
} 
the time, cost and bureaucracy to register a new business. Prior to 2005, an entrepreneur was required to visit several public offices and to complete 11 procedures to register a firm. It took on average 78 days and cost around $13.5 \%$ of GDP per capita in fees. The "On the Spot Firm" program introduced one-stop shops where entrepreneurs can register a company in a single visit, and complete the process in less than an hour, at a cost of $3 \%$ of GDP per capita. The program was progressively rolled out across municipalities over time. ${ }^{4}$ We exploit the cross-municipality-time variation in the implementation of the reform to identify the effect of increased competition on gender discrimination.

Using the roll-out of the program as an exogenous source of increased firm entry and product market competition, we provide quasi-natural experimental evidence on the prediction from Becker (1957) that competition reduces discrimination, reflected in the female employment share and in the gap between the wages of male and female workers. The unusually rich and detailed information from the employer-employee data allows us to control for workers' observable characteristics, such as gender, age, education, skill level, occupation, experience and type of contract of employment. We obtain estimates that also account for worker or firmworker fixed effects, thus controlling for unobserved individual or match heterogeneity and for composition effects. This is a strength of the dataset.

We show that the "On the Spot Firm" program significantly increased firm entry within industries and municipalities, thus increasing product market competition. We find that nondiscriminatory employers, approximated by a larger female employment share, increase employment growth after the reform while discriminatory employers grow slower over time and have a higher probability of exiting the market. The increase in competition following the business entry reform increases growth in the female share, particularly in managerial and high-skill positions, both within firms and across firms in an industry. We also find that the gender pay gap is reduced following the reform for middle-managers, high-skilled and medium-skilled workers in affected municipalities, but not for top-managers or unskilled workers. We obtain a positive and statistically significant differential effect of the reform on the pay of female workers; the coefficients on interaction terms between a female indicator, the reform dummy variable and the skill category of the worker are positive and statistically significant for workers in those categories.

Our estimates imply a reduction in the gender pay gap of 1.7 percentage points for middlemanagers and high-skilled workers and of 1 percentage point for medium-skilled workers. The magnitude of these estimates is equivalent to a reduction in the gender pay gap by $15 \%$ and $13 \%$ for middle-managers and high-skilled workers, respectively, and by $7.6 \%$ for medium-skilled workers, relative to the overall gender pay gap for those categories. We find that while the wage

\footnotetext{
${ }^{4}$ The policy was hugely successful, and as a result Portugal rose from 113th to 26th in the World Bank "Ease of Doing Business" ranking of countries.
} 
of male workers in middle-managerial positions increased by $2.2 \%$, the wage of females increased by a larger $3.9 \%$ as a result of the reform. Males in high-skill jobs experienced a wage increase of $1.3 \%$ while female wage increased by $3 \%$ in treatment municipalities. The wage of medium-skilled males was not affected by the reform, but that of females in the same skill category increased by $1 \%$. Therefore, the business entry reform improved women's relative pay. Our findings are consistent with the prediction from Becker (1957) that product market competition reduces employer discrimination. By increasing the efficiency loss from discriminating against women, competition leads to increased employment growth of the more efficient non-discriminatory employers, and induces discriminatory employers to change their behavior.

We also estimate the effect of the reform on the gender pay gap across the corporate hierarchy, using finer occupational categories; we find that the reform is associated with a narrowing of the gender pay gap for executives, except for the CEO. This suggests that the labor market for top executives still especially favors men and increased competition does not improve female CEOs' relative pay.

Although previous studies investigated the relationship between product market competition and discrimination, evidence is still scant. Most studies focus on cross-sectional correlations or on potentially endogenous time variation, and thus do not explicitly estimate the causal mechanism. By using the "On the Spot Firm" program as a quasi-natural experiment, we are able to identify the causal link between competition and gender discrimination cleanly. Moreover, most previous studies that investigate the relationship between competition and discrimination use industry-level concentration ratios, the Herfindahl-Hirschman index (HHI) or firm-level measures of market power to measure competition. These measures face a number of well known limitations. ${ }^{5}$ By exploiting an exogenous source of increased competition, we avoid the caveats associated with common measures of competition and obtain clean estimates of that relationship.

The focus of most existing papers has been to investigate whether industries with higher degree of concentration or firms with more market power pay females lower wages than males or hire relatively less female workers. An important earlier paper is Ashenfelter and Hannan (1986), which analyses the relationship between product market competition and discrimination in the U.S. banking industry, using a cross-section of geographical markets. Some studies focus on whether firms with lower shares of female employees have lower profits, particularly in more competitive environments. Hellerstein et al. (2002) and Kawaguchi (2007) investigate the relationship between profits and female employment shares across firms with varying degree of market power to examine the implications of Becker's (1957) theory. Weber and Zulehner (2014) investigate how changes in concentration affect the relationship between female employment

\footnotetext{
${ }^{5}$ These include potential endogeneity, correlation with omitted variables and non-monotonicity of their effects on outcome variables (Sutton, 1991).
} 
shares and firm profit or exit probability, based on firm entry and survival in Austria. ${ }^{6}$

Our paper is more related to a branch of empirical studies that use panel data to investigate how changes in competition over time affect female wages or female employment shares. Black and Strahan (2001) exploit the deregulation in the banking industry in the U.S. from the mid-1970s, while Black and Brainerd (2004) focus on increased competition from international trade. These studies find evidence that competition increases the relative wages of females. By exploiting an episode of comprehensive entry deregulation across industries, our natural experiment allows us to obtain results that can be interpreted more generally than in the banking industry, where the structure of compensation could have been marked by idiosyncrasies. By focussing on a more recent period, characterized by deregulation in many countries and by a narrowing of the gender pay gap, we shed light on the link between the two phenomena.

We interpret our findings in the light of preference-based models of discrimination (Becker, 1957) since the theory predicts that increased product market competition will reduce employer discrimination. Another class of economic models focusses on statistical discrimination. Statistical discrimination is the solution to a signal extraction problem and arises when rational, information-seeking, employers use prior information on aggregate group characteristics, such as group-specific means, to evaluate individual characteristics. This can lead to workers with the same observable characteristics being treated differently because they belong to different groups (see Phelps, 1972; Arrow, 1973; and more recently Moro, 2003 and Morrow and Norman, 2004). However, there is not a clear link between product market competition and statistical discrimination. ${ }^{7}$

Our paper is also broadly related to the literature that studies the gender pay gap more generally. Blau and Kahn (2000) review that literature; more recent studies include Blau and Kahn (2016), Goldin (2014) and Bayard et al. (2003).

Our results have important implications for policy that aims to improve product market competition through entry deregulation. Our findings that reducing entry barriers contributes to increase the female employment share growth and narrow the gender pay gap, particularly for medium-skilled, high-skilled and managerial workers, suggests that deregulation also contributes to reduce inefficiencies arising from gender discrimination. Existing evidence shows that gender discrimination significantly reduces output across countries; therefore, our findings are relevant for future policy advice to other countries. ${ }^{8}$

\footnotetext{
${ }^{6}$ Heyman et al. (2013) use employer-employee data from Sweden to analyze how product market competition and firm takeovers affect the gender wage differential and gender workforce composition. Winter-Ebmer (2007) use meta-analysis to study product market competition and gender wage gaps, while List (2004) is an influential example of the experimental literature on the impact of competition on discrimination.

${ }^{7}$ It could be argued that increased competition induces firms to improve management practises, potentially resulting in better screening mechanisms of applicants and less need to rely on group-specific means. But the effect on hiring would depend on the relative change in the signal-to-noise ratio, and on the distributions of group characteristics. Therefore, it is not clear how increased product market competition would affect discrimination in the statistical sense.

${ }^{8} \mathrm{~A}$ number of studies have also shown that entry and competition contribute to productivity growth and
} 
The paper is organized as follows. The next section describes the "On the Spot Firm" program. Section 3 describes the data used and the identification strategy and presents descriptive statistics. Section 4 presents and discusses the results on the effect of the quasi-natural experiment on firm creation, the relationship between gender discrimination and firm growth and survival, growth of the female employment share and the gender pay gap. The last section concludes.

\section{The "On the Spot Firm" business registration reform}

This section describes our quasi-natural experiment, the "On the Spot Firm" business registration reform. The program was introduced in May 2005 by the newly elected government, which took office in March 2005. The objective of the program was to promote national and foreign investment by reducing the cost and bureaucracy of starting-up a firm. To register a new firm in Portugal prior to 2005 an entrepreneur was required to fulfil 11 procedures and to complete 20 forms. The entrepreneur would need to visit separate offices of the Ministries of Justice, Finance, Economy and Labor and Social Security to obtain the necessary documents and approvals. The process took 78 days on average and fees equivalent to $13.5 \%$ of GDP per capita.

In 2005, the new government created a task force, the Unit for Coordination of Administrative Modernization (UCMA), to coordinate across ministries in order to improve the efficiency of public services and reduce the red tape associated with setting up a new firm. This resulted in the introduction of the "On the Spot Firm" (Empresa na Hora) program by the Ministry of Justice. ${ }^{9}$ The program was intended to reduce the time and complexity of the process of registering a firm. The business registration reform was unannounced and unanticipated.

The program introduced one-stop shops - non-profit seeking government offices - where entrepreneurs can register a company at a single office desk in less than an hour, and at a cost of around $3 \%$ of GDP per capita, below the OECD average of $6.8 \% .^{10}$ The legal and commercial registration is completed in the one-stop shops, and the entrepreneur receives the firm identification card and the corporate tax payer and social security numbers in the same day. The information is internally exchanged and sent electronically by the registry authorities to all ministries and authorities involved in the process. ${ }^{11}$

[Figure 1 about here]

innovation (e.g., Djankov et al., 2006; Aghion et al., 2009).

${ }^{9} \mathrm{http}: / /$ www.empresanahora.mj.pt/ENH/sections/EN_homepage.html

${ }^{10}$ World Bank (2006).

${ }^{11}$ State-owned firms or firms in industries with industry-specific requirements or permits are not allowed to be registered in the one-stop shops of the "On the Spot Firm" program. These are mainly in the finance, insurance and transportation sectors. We exclude observations in these industries from our analysis. 
Due to resource constraints and uncertainty about its success, the "On the Spot Firm" program was not introduced simultaneously in all municipalities. Four pilot one-stop shops were opened in July 2005 in the municipalities of Coimbra, Aveiro, Barreiro and Moita. ${ }^{12}$ The program then expanded over time to municipalities across Portugal. By the end of 2009 there were 164 one-stop shops dispersed throughout the country. The geographical dispersion and opening dates of the one-stop shops are shown in Figure 1. As evidenced, the program was progressively rolled-out randomly across municipalities. We exploit this cross-municipalitytime-specific variation in the implementation of the "On the Spot Firm" program to identify the effect of the resulting increase in competition on gender discrimination.

The policy was hugely successful; the total waiting time was reduced by 230,000 days in a year and companies saved around 16 million euros. Portugal is now one of the fastest countries in the world in starting-up a business, and was considered top reformer in business entry in the World Bank Doing Business report.

\section{Data description and identification strategy}

\subsection{Data description}

Our empirical analysis is based on the Portuguese linked employer-employee data, Quadros de Pessoal (QP), collected annually by the Ministry of Labor and Social Solidarity. All private sector firms employing at least one worker are legally required to complete the survey and to make it available at the firm. This results in a high degree of coverage and reliability of the data. In the data, each firm and each worker are assigned a unique time-invariant identifier which allows them to be traced over time.

Worker-level information includes the worker's gender, age, education level (schooling), level of skill, occupation, type of contract of employment, hiring date in the firm, promotions, monthly hours of work (normal and overtime) and earnings, which are split into the components: base wage, seniority payments, regular and irregular benefits and overtime pay. Firm-level data include the year of creation, industry, location, total number of workers, number of establishments, sales volume, legal structure and ownership structure (equity breakdown among domestic private, public or foreign). The information in each year refers to the month when the survey is collected, which is October since 1994.

Our analysis covers the period from 2002 to 2009 and includes private sector manufacturing and services firms, excluding agriculture, fishing and mining, covering 46 industries. The full employer-employee sample includes 438,755 distinct firms (contributing with 1,881,740 firmyear observations) and 3,694,017 workers (contributing 15,340,574 worker-year observations)

\footnotetext{
${ }^{12}$ Administratively, Portugal is divided into 308 municipalities which are the seat of local administrative and executive power.
} 
over the period. ${ }^{13}$ We identify firm entry using the variable that reports the year of creation of the firm. A firm is an entrant in year $t$ if the reported year of creation is $t$ and the firm is observed for the first time in the data in $t .{ }^{14}$ Table 1 shows the distribution of all firms and entrants in each year, as well as workers. Column (3) reports the share of new firms created in municipalities with "On the Spot Firm" one-stop shops. In 2005, $20 \%$ of the newly created firms were registered in municipalities where the reform had been implemented, increasing to $76 \%$ in 2009. Overall, in our data 47,716 firms were created in treatment municipalities.

[Table 1 about here]

The main dependent variable in our specifications is the (natural log of) real hourly wage of the worker; this is obtained by summing the monthly base pay, which is the gross wage for the normal hours of work, tenure related payments, and regular benefits, and then dividing by the normal hours of work. The hourly wage is then deflated to obtain the real wage. We use information in the QP data on the educational level and occupational category of each worker. The level of education is classified according to the UNESCO International Standard Classification of Education (ISCED) of 1997. ${ }^{15}$ Occupations are classified according to the International Standard Classification of Occupations of 1988 (ISCO-88). We exploit information on the occupational category of the workers to investigate the effect of the reform on the gender pay gap for CEOs, department managers and other workers. We use the 3-digit level ISCO-88 occupations to distinguish CEOs (individuals in ISCO category 121), department managers (individuals in the categories 122 and 123) and other workers (all other occupational categories). ${ }^{16}$

In the QP data workers are also classified according to eight qualification levels based on the position in the firm's hierarchy and on the complexity, responsibility and skill requirement of the tasks they perform. ${ }^{17}$ Appendix Table A.1 describes in detail the hierarchical levels and their skill content in accordance with the law. ${ }^{18}$ We exploit this information to investigate the effect

\footnotetext{
${ }^{13}$ The final estimation sample is smaller due to missing data for some variables.

${ }^{14}$ Since the data is collected in October each year, we recover information on firm births when the reported year of creation is $t-1$ but the firm is first observed in $t$. In those cases the firm is considered an entrant in $t$.

${ }^{15}$ The correspondence between ISCED levels and years of schooling in Portugal is: ISCED 1 - first and second stages of basic education (up to 6 years of schooling); ISCED 2 - lower secondary education (9 years of schooling); ISCED 3 - upper secondary education (12 years of schooling); ISCED 5/6 - higher education (more than 15 years of schooling, corresponding to university degrees). In Portugal, there is no degree corresponding to ISCED level 4; and it is not possible to distinguish between ISCED levels 5 and 6 from the data.

${ }^{16}$ ISCO88 category 121 is "Directors and Chief Executives"; ISCO88 122 is "Production and Operations Department Managers"; and ISCO88 123 is "Other Department Managers" (including Finance and administration, Personnel and industrial relations, Sales and marketing, Advertising and public relations, Supply and distribution, Computing services, Research and development, Other). The category "Directors and Chief Executives" can include top executives other than the CEO, but firms in our sample have on average (and median) one individual in that category; and we refer to them as CEOs.

${ }^{17}$ The levels are: 1 - Top executives (top management); 2 - Intermediary executives (middle management); 3 Supervisors, team leaders and foremen; 4 - Higher-skilled professionals; 5 - Skilled professionals; 6 - Semi-skilled professionals; 7 - Non-skilled professionals; 8 - Apprentices, interns and trainees.

${ }^{18}$ They are established in the Law Decree no. $121 / 78$ of July.
} 
of the business registration reform on the gender pay gap for workers in different skill categories and across the corporate hierarchy. For that analysis, we aggregate the skill levels and define five categories: top-management (level 1), middle-management (levels 2 and 3), high-skilled (level 4), medium-skilled (level 5) and low-skilled (levels 6 to 8). We also use that variable to identify the effects of the reform on the gender pay gap for managerial workers (those in levels 1 and 2) relative to all other workers in the corporation.

Table 2 reports detailed summary statistics of the log real wage for each skill and occupational category and managerial position. As shown in the table, CEOs are the group of workers with higher average log real hourly wage, followed by department managers, managerial workers and high-skilled workers. Within each category, we also report statistics for female and for male wages. In all categories, the average and median wages are always lower for females than for males. We will investigate in the next sections these gender pay gaps in a regression setting and how the increased competition following the firm entry reform affected the gender pay gap for workers in different skill categories and occupations.

[Table 2 about here]

In our specifications, we control for the workers' observable characteristics, including gender, education, tenure and its square and the type of contract of employment (whether open-end or closed-end). Observable firm characteristic are also controlled for, including the log of firm size (number of employees), ownership type (private, public or foreign), whether the firm is an exporter, and whether the firm is multi-plant. To obtain information on exporters, we merge the employer-employee data with data from the International Trade dataset collected by the Portuguese National Institute of Statistics. In Appendix Table A.2 we present descriptive statistics of all variables for the full sample (column 1) as well as by skill category (columns 2-6), for managerial and non-managerial workers (columns 7 and 8) and by occupation (columns 911). Overall, female workers account for $45 \%$ of the observations in our data, but in the sample of CEOs, only $19 \%$ of observations are for females. Although only about $9 \%$ of observations are for workers with a university degree, this proportion is significantly higher in the group of high-skilled workers (24\%), CEOs (74\%) and managerial workers (59\%). This suggests that our measure of the skill requirement of the tasks performed by a worker is not a direct outcome of educational attainment. Regarding the "On the Spot Firm", 35\% of observations are located in municipalities with one-stop shops. Table A.3 reports summary statistics of firm-level covariates.

\subsection{Identification strategy}

To identify the effects of increased product market competition on gender discrimination, we exploit the roll-out of the "On the Spot Firm" program across municipalities over time. We use 
the variation in the timing of adoption across municipalities for identification. The effect of the reform on the outcomes of interest, particularly on the gender pay differential, is thus identified off cross-municipality differences in the reform implementation over time. The treatment group includes firms and individuals in municipalities that introduced the "On the Spot Firm" program. The treatment variable in our empirical specifications is $\operatorname{Spot}_{m t}$, which takes the value 1 in the year $(t)$ when the program is adopted in municipality $m$ and in all subsequent years, and 0 otherwise.

As discussed above, the policy change was unanticipated, and exogenous. The empirical strategy relies on the assumption that the program was not introduced in a systematic way across municipalities; specifically, that it is not correlated with pre-existing trends in the variables of interest. In our regressions, among a host of factors that may affect the outcomes, we control for municipality fixed effects, which absorb any differences across municipalities. However, we start by showing that the order of adoption of the "On the Spot Firm" across municipalities is uncorrelated with previous trends in the variables used in our analysis.

Table 3 reports pre-reform average growth (over 2002-2004) for the variables of interest, for the group of municipalities that adopt the reform later, from 2007 onwards (column 1), and for the group that adopt in the first years, 2005 and 2006 (column 2); as well as the difference between the two (column 3). We test whether growth trends prior to the policy change differ between early and late adopting municipalities; column (4) reports the p-value for the null hypothesis that the means are equal for both groups. We find that there are no statistically significant differences for any of the variables of interest. This evidence shows that the order in which municipalities introduced the program is not correlated with pre-reform trends in wages, firm creation, firm growth, female employment share growth and the gender pay gap, strongly supporting the identification strategy.

[Table 3 about here]

\section{Empirical analysis}

\subsection{Effect of the "On the Spot Firm" reform on firm entry}

This section investigates the effect of the "On the Spot Firm" business registration reform on firm entry. This analysis assesses the validity of the reform as an exogenous source of increased firm entry, and competition, for the main analysis of the paper, on the effects on gender discrimination. In particular, our main interest is in investigating the prediction that increased competition reduces the gender pay gap.

We start by showing in Figure 2 average firm entry in municipalities that adopt the reform, in each year before and after adoption; that is, for each lag and lead relative to the year 
of implementation in each municipality. As shown in the figure, we observe that firm entry started to increase substantially in affected municipalities since the year when the reform is implemented. The figure thus suggests that the business registration reform has led to increased firm entry. ${ }^{19}$ While the figure depicts raw averages in firm entry over time across industries and municipalities that adopt the reform, it does not take into account municipality and industry characteristics, unobserved heterogeneity, or general trends across all municipalities. For this, we turn to our regression analysis.

[Figure 2 about here]

We studied the effect of the "On the Spot Firm" program on firm entry in previous work (Fernandes et al., 2014, 2018) and this analysis draws from that work. To study the effect of the reform on firm creation, we estimate the following specification, for the period from 2002 to 2009:

$$
Y_{m s t}=\beta \operatorname{Spot}_{m t}+d(.)+\epsilon_{m s t}
$$

Where the dependent variable, $Y_{m s t}$, is the number of new entrant firms by municipalityindustry-year $(m s t)$ or alternatively, the ratio between the number of new firms and the number of incumbents. Spot St $_{t}$ is the "On the Spot Firm" experiment indicator variable; it is equal to one in the year when the "On the Spot Firm" reform is adopted in municipality $m$ and in all subsequent years, and it is equal to zero otherwise. ${ }^{20}$ We control for industry fixed effects, $d_{s}$, which absorb any industry characteristics that may affect firm entry, year fixed effects, $d_{t}$, to account for aggregate trends and municipality fixed effects, $d_{m}$, which account for any unobserved municipality characteristics that could be related to firm entry, particularly any differences between treated and non-treated municipalities. The standard errors are clustered by municipality, the level at which the reform is introduced, to account for potential correlation between observations within municipalities. We expect that the entry deregulation led to increased firm entry; therefore, the estimate of the coefficient on the Spot variable, $\beta$, is expected to be positive and statistically significant.

The results from estimating equation (1) are presented in Table 4. Columns (1) and (2) report results for the number of new firms as the dependent variable. We include different

\footnotetext{
${ }^{19}$ We find a significant increase in the number on new entrant firms following the reform. However, the entry size of startups did not change following the entry reform. In particular, as shown in Appendix table A.3, the average size of "On the Spot Firm" entrants is 3.9 workers, while the average entry size before the reform and in non-adopter municipalities is 4 . Moreover, the overall average firm size in Portugal is small, with a distribution characterized by a large mass of small firms and some large firms; the average incumbent size is 9.7 workers and average entrant size is 4 . It is therefore expected that the increased firm entry within a municipality-industry cell increases product market competition at that level.

${ }^{20}$ Some municipalities introduce additional one-stop shops in subsequent years. The treatment dummy variable is set to one after the first shop is opened because from then onwards, the program is in effect, and an entrepreneur can register a firm in the "On the Spot Firm" office.
} 
sets of fixed effects, as explained above. As shown, the firm entry reform is associated with an increase in the number of new firms: we obtain a positive and statistically significant coefficient on the Spot variable. This result is obtained in both the linear model presented in Table 4, as well as in a negative binomial regression, presented in Appendix Table A.4. The linear estimates imply that, controlling for municipality, year and industry fixed effects (column 2), the number of new firms increased by $18 \%$ within industries and municipalities following the reform, relative to the sample mean.

In columns (3) and (4), we use as alternative dependent variable the ratio between the number of new firms and the number of incumbents. The results remain robust; the coefficient on the Spot variable remains positive and statistically significant. The estimate of 0.009 in column (4) implies that the ratio of new firms to incumbents increased by about 1 percentage point, which is equivalent to a $14 \%$ increase relative to the sample mean $(7 \%)$. These results show that the "On the Spot Firm" policy is associated with a statistically significant and economically important increase in firm entry, and thus product market competition. Our results on entry deregulation are consistent with those in Bruhn (2011), who finds that a similar reform in Mexico increased the number of new business registrations by $5 \%$ and employment by $2.2 \%$; and with Branstetter et al. (2014), who use the same reform as in this paper and find that it is associated with an increase in the number of new firms per 100,000 inhabitants of around $17 \%$.

[Table 4 about here]

In the specifications reported in Table 4, we identify the average effect of the "On the Spot Firm" reform on firm entry over the entire post-reform period. Next, we estimate the effects in each year before and after the reform, thus assessing whether the effects vary with the duration of the program. We estimate a specification which includes a set of dummy variables, $S_{p o t}$, , for each lag and lead, $l$, relative to the year of implementation of the reform in a given municipality, $m$. In this specification, each coefficient is estimated relative to the period prior to t- 4 and to non-adopters. Figure 3 presents the estimated coefficients for each lag and lead year and the 95\% confidence interval (CI) from a specification with the number of new firms as dependent variable and with industry, municipality and year fixed effects. The dots on the solid line show the estimated coefficients, and the two dashed lines the $95 \%$ confidence bands of the estimates.

As Figure 3 shows, we find that the estimated coefficients are close to zero and statistically insignificant in the years prior to the "On the Spot Firm" program. The effect of the program on firm entry becomes positive and statistically significant in the year of adoption. The effect increases over time after adoption, with an increase in business registration. The coefficients on the Spot terms are always positive and statistically significant in all periods after the reform is implemented. ${ }^{21}$

\footnotetext{
${ }^{21}$ The effect seems to start decreasing in $t+4$; however, as the lags and leads increase, identification relies on
} 
[Figure 3 about here]

In sum, this section shows that the "On the Spot Firm" reform significantly increased firm entry in affected municipalities. In the following sections we use the reform as a quasinatural experiment, which exogenously increased firm entry and product market competition, to estimate the effects on the relationship between gender discrimination and firm growth and survival, growth of the female employment share and the gender pay gap in different skill categories and across the corporate hierarchy.

\subsection{The "On the Spot Firm" reform, gender discrimination and firm growth and survival}

According to Becker's (1957) hypothesis, discriminatory employers satisfy their prejudiced preferences at the expense of profits. Increased product market competition should therefore drive discrimination out of the market, as competitive pressure forces discriminatory employers to exit the market or submit to market pressure and change their behavior. Since competition increases the efficiency loss from discriminating, it is expected that with increased product market competition surviving discriminatory employers grow less over time relative to non-discriminatory employers. That is, non-discriminatory employers should increase overall employment growth, relative to discriminatory firms. Having shown above that the "On the Spot Firm" business registration reform led to increased firm entry in affected municipalities, in this section we investigate the effect of the reform on the relationship between firm employment growth and the level of discrimination, approximated by the female share in the workforce. We estimate the following specification, at the firm-year level:

$$
\Delta \ln \left(N_{j m t}\right)=\beta_{1}\left(\text { Femsh }_{j, t-1} \times \operatorname{Spot}_{m, t-1}\right)+\beta_{2} \operatorname{Spot}_{m, t-1}+\beta_{3} \text { Femsh }_{j, t-1}+\lambda Z_{j t}^{\prime}+d_{(\cdot)}+\epsilon_{j m t}
$$

The dependent variable is employment growth for firm $j$, in municipality $m$, between years $t-1$ and $t\left(\ln N_{j m t}-\ln N_{j m, t-1}\right)$. Femsh is the proxy for discrimination: the share of females in the firm's workforce. We use two alternative measures, the previous period female employment share and, alternatively, the female share in the year prior to the introduction of the reform, for each firm. The latter allows us to assess whether less discriminatory firms prior to the reform grow faster after the reform is implemented, relative to discriminatory firms. We include firm observed characteristics in matrix $Z_{j t}^{\prime}$ : ownership type (domestic private, public or foreign), a dummy for whether the firm is an exporter and a dummy for whether the firm is multi-plant. We also include year fixed effects $\left(d_{t}\right)$ in our specifications to account for global trends, and

fewer municipalities to estimate the effects, that could explain the lower coefficient. For example, for lead $t+4$, estimation is based only on municipalities that adopt in 2005 . 
control for municipality $\left(d_{m}\right)$ and industry $\left(d_{s}\right)$ fixed effects or, in alternative specifications, for firm fixed effects $\left(d_{j}\right)$; these absorb unobserved municipality, industry or firm characteristics that may affect firm growth.

The coefficient of interest in equation (2) is $\beta_{1}$, on the interaction between the female-share proxy for discrimination and the reform dummy variable, $F e m s h_{j, t-1} \times \operatorname{Spot}_{m, t-1}$. We expect $\beta_{1}$ to be positive; that is, a positive relationship is expected between the female share and overall employment growth following the reform. Non-discriminatory employers, approximated by higher female shares, should grow faster relative to the less efficient prejudiced employers.

Table 5 presents the results from linear regressions of the growth in employment in surviving firms. Panel A uses the sample of all firms. In columns (1) and (2) we use the lagged timevarying female employment share to proxy for discrimination, while in columns (3) and (4) we use as alternative discrimination proxy the female share in the year prior to the introduction of the reform. Even-numbered columns include year and firm fixed effects, thus accounting for firms' unobservable characteristics.

We obtain a positive and statistically significant coefficient on the interaction term of main interest, Femsh ${ }_{j, t-1} \times$ Spot $_{m, t-1}$, showing that a higher female employment share is associated with increased firm employment growth following the reform. That is, the less discriminatory firms have higher employment growth. This is observed both across firms in an industry as well as within firms. The estimated coefficient of 0.013 in column (2) implies that following the reform, a one standard deviation increase in the female fraction (0.41) is associated with higher firm employment growth by 0.5 percentage points. The results are robust for the alternative discrimination proxy, in column (4). The stand-alone Spot coefficient is negative and statistically significant, showing that the less efficient discriminatory employers reduce employment growth after the business entry reform.

These results show that there is a positive differential effect of the reform on firm employment growth for non-discriminatory employers, approximated by a larger female share. This is consistent with the hypothesis that non-discriminatory employers expand employment following increased competition, relative to discriminatory employers.

[Table 5 about here]

The share of females in the workforce as a proxy for employer discrimination is more revealing about employers' tastes for larger firms than for smaller firms. For example, a very small firm has a positive probability of ending up with a higher share of males even if the employer is not gender biased; but this probability decreases with firm size (see also Weber and Zulehner, 2014). Therefore, we should find stronger effects of the female share on employment growth for larger firms, if the relationship captures the effect of discrimination. In Panel B of Table 5, we estimate 
the same specifications but for a sample that excludes very small firms: those with less than 10 workers throughout. We continue to find that the coefficient on the $F_{e m s h}{ }_{j, t-1} \times \operatorname{Spot}_{m, t-1}$ term is positive and statistically significant. As expected, the effects are now stronger; the magnitude of the estimates is larger in the sample of larger firms. In the preferred specifications, with firm fixed effects (columns 2 and 4), we find that while discriminatory employers, with low female shares, reduce employment growth with the increased competition following the reform, non-discriminatory employers increase overall employment growth. These findings support the hypothesis that increased competition reduces discrimination by reallocating market shares to the more efficient non-discriminatory firms.

Next, we examine whether the competitive pressure following the reform contributes to increase the probability that discriminatory employers exit the market. We estimate specifications similar to equation (2) above, but for the firm's exit probability dummy variable. The dependent variable in these specifications, Exit $t_{j m t}$, takes the value 1 if the firm exits the market in year $t$ and zero if it survives. To avoid a bias from the relationship between firm size and survival, we use the sample that excludes very small firms, with less than 10 workers. ${ }^{22}$ The interaction between the female-share proxy for discrimination and the reform dummy variable, Femsh $_{j, t-1} \times$ Spot $_{m, t-1}$, captures whether less discriminatory employers - approximated by a higher female share - have a lower exit probability after the "On the Spot Firm" reform, relative to discriminatory employers.

It is a well known result that competition increases the probability of firm liquidation (e.g. Schmidt, 1997). Therefore, on the one hand, increased firm entry following the reform is expected to increase the firm exit probability, on average. On the other hand, if competition contributes to drive discrimination out of the market, the exit probability is expected to be relatively higher for the less efficient discriminatory firms.

We also consider a regression that allows the relationship between the reform and the firm exit probability to vary by quartiles of the firms' female share distribution. We divide firms into four quartiles of the female share distribution in the year prior to the introduction of the reform, since the quartiles remain constant for a firm, and define quartile dummies, $I_{j q}^{F e m s h}$, which take the value 1 if firm $j$ is in quartile $q(q=1, \ldots, 4)$ of the female share distribution, and zero otherwise. ${ }^{23}$ We then estimate a specification with interaction terms between the "On the Spot Firm" variable and the discrimination proxy quartile dummies, $\operatorname{Spot}_{m, t-1} \times I_{j q}^{F e m s h}$.

[Table 6 about here]

\footnotetext{
${ }^{22}$ As discussed above, the share of females as a proxy for employer discrimination is also more revealing about employers' tastes for larger firms than for smaller ones.

${ }^{23}$ Quartile 1 is the lowest female share quartile, and quartile 4 is the highest.
} 
Table 6 reports the results. In columns (1) and (2), we find that the coefficient on the stand alone Spot variable is positive, and is statistically significant when firm fixed effects are included (column 2). This shows that increased competition following the reform raises the probability of firm exit, on average, controlling for firm characteristics and for the exhaustive sets of fixed effects. The coefficient on the interaction term between the reform variable and the discrimination proxy $\left(F e m s h_{j, t-1} \times S p o t_{m, t-1}\right)$ is negative, as expected, but statistically insignificant.

In columns (3) and (4), we estimate a more flexible specification that allows the relationship between the reform and the exit probability to vary by quartiles of the discrimination proxy distribution. The stand-alone Spot term shows that firms at the bottom of the female share distribution (the reference group) have the highest probability of exiting the market after the reform. The exit probability increases more after the reform for the most discriminatory firms.

Importantly, the coefficients on the quartile interaction terms are negative and statistically significant for firms in the second and third quartiles of the female share distribution, showing that less discriminatory firms have a lower probability of exiting the market, after the policy change, relative to more discriminatory firms. The negative relationship is also increasing in the discrimination proxy; the coefficient is larger (more negative) for firms in the third quartile than for those in the second, showing that firms with a higher female share have a lower probability of exiting after the reform. ${ }^{24}$ These results provide evidence that more discriminatory firms have increased probability of exiting the market following an increase in competition, in line with Becker's prediction that competition drives discriminatory employers out of the market.

\subsection{Effect of the "On the Spot Firm" reform on growth of the female em- ployment share}

In this section, we investigate whether the firm entry reform affected growth of the share of female employment at the firm-level. That is, we assess the change in the gender workforce composition following the policy change. Since discrimination is costly, and as shown in the previous section, discriminatory employers reduce overall employment growth, and have higher probability of exiting the market, it is expected that the reform, and the increased competition it induced, increased demand for female labor. As discussed in Black and Strahan (2001), discriminatory employers could also prefer to keep women in lower positions than implied by their skills. The increased competition would therefore be associated with increased growth of the female employment share, particularly in high-skill positions.

We test whether the growth rate of the females share, in total employment and in each

\footnotetext{
${ }^{24}$ The coefficient on the fourth quartile interaction term is negative but statistically insignificant. Firms in the fourth quartile have a very large female share ( 0.9 on average) and are in sectors where traditionally the work is predominantly performed by females, such as textiles and apparel.
} 
occupation or skill category, increased following the "On the Spot Firm" policy change. We estimate specifications at the firm-year level, where the dependent variable is the growth rate in the female employment share. ${ }^{25}$ The explanatory variable of interest is the "On the Spot Firm" indicator, Spot. We control for industry, municipality and year fixed effects in our specifications, and in alternative specifications for firm and year fixed effects, to estimate from changes within firms. We also control for firm observable characteristics, as explained above.

[Table 7 about here]

Table 7 reports the results. Panel A presents results with industry, municipality and year fixed effects. In column (1) we regress growth in the share of females in total employment on the reform variable. The coefficient on the "On the Spot Firm" variable is positive and statistically significant and implies an increase in the female employment share growth of 1.4 percentage points. The remaining columns of the table report results when the dependent variable is the share of females in each skill or occupational category. The coefficient on the reform indicator is positive and statistically significant for the female share growth in all skill categories, except medium-skill. The estimated effect in column (2) implies a 2.5 percentage point increase in growth of the female share in managerial positions following the firm entry reform. The effect for high-skilled is estimated at 2.3 percentage points. In Panel B, we include firm and year fixed effects, to estimate the effect within firms following the reform. We continue to find that the reform is associated with increased growth in the female share. The effect on the growth of the female share in managerial positions remains positive but the statistical significance is reduced.

Similar to Figure 3 above, in Figure 4 we report the estimated coefficients for each lead and lag, relative to the year of adoption of the reform in each municipality, from a specification for growth in the female share in total employment, controlling for firm and year fixed effects. We continue to find that the effect increases over time after adoption, with the duration of the program.

[Figure 4 about here]

In sum, the results in this section suggest that the increased competition following the reform induced firms to increase growth of the share of female employment. This is obtained both across firms in an industry as well as within firms. The effects are larger for the female share in managerial and high-skill positions. The results are consistent with the prediction that competition leads to increased demand for female workers. In the next section we investigate the effects of the reform on the gender pay gap.

\footnotetext{
${ }^{25}$ We use the difference in the $\ln ($ female share+0.001) to account for cases where the share is zero.
} 


\subsection{Effect of the "On the Spot Firm" reform on the gender pay gap}

This section exploits the reform as a quasi-natural experiment to study how the exogenous increase in competition affects compensation, and in particular the pay differential between male and female workers. According to Becker's (1957) theory, since discrimination increases costs, in competitive environments employers have no room to indulge their tastes for gender discrimination. Therefore, we expect that the exogenous shock to product market competition following the "On the Spot Firm" program will have contributed to improve female workers' relative compensation. Our identification exploits the cross-municipality-time variation in the implementation of the program to estimate the effect of the reform on the gender pay gap.

We start by showing in Figure 5 average log real wage for males and females in each skill category, in each year before and after the reform was implemented in each municipality. The solid line represents the overall mean and the dotted lines the means for male and female wages. As shown, the pay gap between male and female workers starts to narrow, with female wages increasing faster than male wages, since the year when the reform is implemented. That is observed particularly for middle-managers and for high- and medium-skilled workers. The gap between male and female wages continues to narrow in the years after adoption of the reform, with the increase in business registration. The figure suggests that the business registration reform has contributed to narrow the gender pay gap for those workers, in affected municipalities. But while the figure shows raw average wages over time, it does not take into account workers' and firms' characteristics, unobserved worker heterogeneity, or general trends in wages in all municipalities. To estimate the effect of the reform on the gender pay gap accounting for those factors, we turn to our regression analysis below.

[Figure 5 about here]

As a point of comparison with existing studies, we start by estimating the general gender pay gap. We estimate a compensation regression with a female dummy included:

$$
\ln w_{i j m t}=\alpha+\beta F e m_{i}+\gamma X_{i t}^{\prime}+\lambda Z_{j t}^{\prime}+d_{(\cdot)}+\epsilon_{i j m t}
$$

The dependent variable is the natural $\log$ of real hourly wage of worker $i$ (in firm $j$, municipality $m$ ) in year $t .{ }^{26} \mathrm{Fem}_{i}$ is a female dummy. We control for individual observed characteristics, such as education, skill level, tenure and its square, occupation and type of employment contract in matrix $X_{i t}^{\prime}$. Firm characteristics are included in matrix $Z_{j t}^{\prime}$ : the log of size, ownership type (domestic private, public or foreign), a dummy for whether the firm is an exporter and a dummy for whether the firm is multi-plant. We also control for industry $\left(d_{s}\right)$, municipality $\left(d_{m}\right)$ and

\footnotetext{
${ }^{26}$ Hourly wage is calculated as the sum of the base wage and regular contributions divided by hours of work.
} 
year $\left(d_{t}\right)$ fixed effects in our specifications to absorb unobserved industry and municipalityspecific characteristics that may affect compensation, in particular the gender pay differential, and global shocks that affect all firms and workers. In alternative specifications we include firm fixed effects, thus estimating the gender pay gap within the same firm, controlling for all worker's and firm's observable characteristics. $\epsilon_{i j m t}$ is a random error term. A statistically significant coefficient on the female dummy $(\beta)$ captures the wage gap between males and females, assuming that the worker controls included, such as education, tenure and skill level, account for differences in worker productivity.

The results from estimating equation (3) are reported in Table 8. Our data has the advantage, relative to most previous studies, of including information on the level of education and the skill level of each worker. Therefore, we obtain results that control for a comprehensive set of workers' characteristics, accounting for differences in productivity across workers. We find that the gender pay gap is still sizable. Our estimates in column (1) show that, controlling for municipality, industry and year fixed effects, there is a $13.4 \%$ difference in the level of pay between male and female workers. This is consistent with existing studies of the gender pay gap; for example, Blau and Kahn (2016) report estimates of around $18 \%$ for the gender pay gap in the US. In column (2) we include firm fixed effects and find that within the same firm, the gender pay gap is estimated at $12.8 \%$. The differential in pay between male and female workers, obtained after controlling for worker's characteristics that capture among other things differences in productivity, is often interpreted as an estimate of employer discrimination - that is, male and female workers with equal qualifications and skills do not share equal pay.

[Table 8 about here]

Next, we investigate how the "On the Spot Firm" business registration reform affects employer discrimination by estimating its effects on the gender pay gap. Existing evidence has shown that the gender pay gap declined at different rates across the wage distribution; particularly, it has declined much more slowly at the top of the wage distribution than at the bottom, and in recent years remained significantly higher at the top (Blau and Khan, 2016). It is therefore relevant to assess how competition affects the gender pay gap for workers in jobs that require different skill levels or in different occupations. We investigate how increased competition following the business registration reform affects the gender pay gap across the skill distribution and across the corporate hierarchy. To that end, we estimate specifications of the form:

$$
\begin{aligned}
\ln w_{i j m k t}= & \alpha+\beta_{1}\left(\text { Fem }_{i} \times S_{k, i t} \times \operatorname{Spot}_{m t}\right)+\beta_{2}\left(\text { Fem }_{i} \times S_{k, i t}\right)+\beta_{3}\left(\text { Fem }_{i} \times \text { Spot }_{m t}\right) \\
& +\beta_{4}\left(S_{k, i t} \times \text { Spot }_{m t}\right)+\beta_{5} \text { Spot }_{m t}+\beta_{6} S_{k, i t}+\gamma X_{i t}^{\prime}+\lambda Z_{j t}^{\prime}+d_{(\cdot)}+\epsilon_{i j m k t}
\end{aligned}
$$


The dependent variable is the natural $\log$ of real hourly wage of worker $i$ (in firm $j$, municipality $m$, with skill level $k$ ) in year $t$. As above, $F e m_{i}$ is a female dummy and $S_{p o t} t$ is the reform indicator variable. $S_{k, i t}$ is a vector of $k$ indicator variables for the skill category of the worker or, in other specifications, the worker's occupation. As explained in Section 3, we obtain five skill or hierarchical categories using the classification of workers in the firms' hierarchy, presented in Table A.1. We assign workers to top-management (level 1), middle-management (levels 2 and 3), high-skill (level 4), medium-skill (level 5) and low-skill positions (levels 6 to 8). We control for the same observed individual characteristics as above, included in $X_{i t}^{\prime}$, and for firm characteristics in $Z_{j t}^{\prime}$. We continue to include year $\left(d_{t}\right)$, industry $\left(d_{s}\right)$ and municipality $\left(d_{m}\right)$ or firm $\left(d_{j}\right)$ fixed effects.

In addition to the other variables and controls discussed above, the linked employer-employee data that we use allows us to also include worker or worker-firm (match) fixed effects in our regressions, $d_{i}$ and $d_{i j}$, respectively. Therefore, we obtain results that account for individual heterogeneity in the structure of compensation and patterns of job mobility, and for sorting of workers across firms. ${ }^{27}$ We cluster the standard errors by municipality, the level at which the policy was introduced. We interact all variables with the female dummy, thus allowing all right-hand side variables to vary by gender, including the municipality, industry and year dummies; the latter capture for example, potential general differences in wage trends between men and women.

The coefficients of interest in Equation (4) are those on the interaction terms between the female dummy, the reform variable and the skill level of the worker, $F e m_{i} \times S_{k, i t} \times S_{p o t} t_{m t}$. A positive coefficient is consistent with a positive differential effect of the reform on female pay, relative to male pay, in affected municipalities, implying a reduction in the gender pay gap. That would be consistent with Becker's prediction that competition reduces discrimination.

The estimation results are reported in Table 9. In column (1), we present the results for the overall gender pay gap within firms, controlling for worker and firm observable characteristics. ${ }^{28}$ As reported above, the overall gender pay gap within firms is estimated at $12.8 \%$. In column (2), we interact the female dummy with the skill categories, to estimate the gender pay gap in each skill or hierarchical category. We find that the gender pay gap is higher at the top of a corporation, for top executives, estimated at $22.5 \%$, followed by medium- and high-skilled workers, with gender pay gaps of $14.5 \%$ and $13.6 \%$, respectively. The gap in wages between genders is lowest for unskilled workers. These results are consistent with evidence that the gender pay gap is higher at the top of the wage distribution than at the bottom.

\footnotetext{
${ }^{27}$ Match worker-firm fixed effects account for ex-ante sorting but not for trends; e.g., if workers whose productivity is improving were to select into increasingly more competitive industries and firms.

${ }^{28}$ We estimate this specification without worker fixed effects to obtain the coefficient on the female dummy, to assess and interpret the magnitude of the effects of the reform.
} 
[Table 9 about here]

Columns (3) and (4) report our main results, from estimating equation (4), to investigate the effect of the reform on the gender pay gap for workers in each skill level. Each element in $\beta_{1}$, the vector of coefficients on the triple interaction terms, captures the differential effect of the reform on the wage of female workers in skill category $k$, relative to the wage of males in the same skill category. The interaction terms $S_{k, i t} \times$ Spot $_{m t}$ capture the effect of the reform on male wages in each skill category, while the stand-alone $S_{p o t} t_{m}$ term captures the effect for unskilled male workers (the omitted category). The interaction $\mathrm{Fem}_{i} \times \mathrm{Spot}_{m t}$ measures the differential effect for females in the unskilled category.

In column (3) we control for worker fixed effects in addition to all other controls and fixed effects discussed above. We find that the coefficients on the triple interaction terms capturing the differential effect of the reform on the pay of female workers in each skill category, $\mathrm{Fem}_{i} \times$ $S_{k, i t} \times$ Spot $_{m t}$, are positive and statistically significant for middle-managers and for high- and medium-skilled workers. That is, female skilled professionals and middle-managers in affected municipalities experienced an additional increase in pay, relative to males, following the reform. The pay of females in the high-skill and middle-managerial categories increased by an additional $1.6 \%$ and $1.5 \%$, respectively, and of those in the medium-skill category by an extra $1 \%$, relative to males with the same skills.

Results remain robust in column (4), where we include worker-firm (match) fixed effects, and thus identify the differential impact of the reform on female pay from workers that remain in the same firm after the policy change. This ensures that unobserved changes in composition of employment are not driving the results. The estimated coefficients imply that the gender pay gap is reduced by 1.7 percentage points for middle-managers and high-skilled workers, and by 1 percentage point for the medium-skilled. The magnitude of these estimates is equivalent to a reduction in the gender pay gap by $15 \%$ and $13 \%$ for middle-managers and high-skilled workers, respectively, and by $7.6 \%$ for medium-skilled workers, relative to the overall gender pay gap for those categories.

The interaction of the Spot variable with the female dummy is statistically insignificant showing that the reform had no effect on the gender pay gap for unskilled workers. We also find that the stand alone Spot term is statistically insignificant, implying that there are no statistically significant effects of the reform on unskilled workers' overall pay. However, the coefficients on the interaction $S_{k, i t} \times$ Spot $_{m t}$ are positive and statistically significant for managerial and high-skilled workers. That is, workers in top- or middle-managerial positions and those in highskill jobs in affected municipalities experience a positive and statistically significant effect of the firm entry reform on their wage. In particular, high-skilled workers' wage is on average $1.3 \%$ higher after the reform, while the wage of top-managers and middle-managers increased 
by $3.3 \%$ and $2.2 \%$, respectively. An explanation for the increase in the pay of workers in these categories is that due to the entry of new firms there is increased demand for managerial and high-skilled workers, and given inelastic supply of these professionals, their wage increases after the reform.

The specifications reported in Table 9 are equivalent to running separate regressions for male and female workers, since all the variables are interacted with the female dummy. In Appendix Table A.5 we present results from separate regressions for illustration. As shown in columns (1) and (2), the overall wage of medium-skilled males was not affected by the reform, but the wage of females in the same skill category increased by $1 \%$ in treatment municipalities. For those in high-skill jobs, while male wage increased by $1.3 \%$, females saw their wage go up by $3 \%$ as a result of the increased competition following the entry reform. The wage of middle-managers increased by $2.2 \%$ for males while for females it increased by a larger $3.8 \%$. For top-mangers, male pay in affected municipalities increased by $3.3 \%$ and females' by $3.8 \% .^{29}$

An implication from Becker's model is that discriminatory employers pay women less than equally productive men. They optimize when workers' marginal product is equal to their marginal cost (wage plus the disutility cost if the worker is a woman). The gender wage gap will thus be larger the larger the disutility from employing women. To reconcile the differential effects across the skill distribution with a theory based on preferences would require an ad-hoc assumption that employers' preferences differ in intensity by the workers' skill level. For example, that employers hold more prejudice against women in high-skill positions or in managerial positions. With that assumption, increased product market competition would be expected to reduce the gender pay gap by more for workers in those skill levels or positions since the strength of discrimination was initially higher for those workers.

Overall, the results in Table 9 imply that the entry reform is associated with a narrowing of the gender pay gap, except for unskilled workers and for top-managers, and provide empirical support for the prediction that increased product market competition reduces discrimination, reflected in lower female wages. Our findings thus provide quasi-natural experimental evidence for the dynamic implication from Becker's (1957) theory: discrimination is hard to sustain in a competitive environment and increased competition contributes to reduce discrimination.

In the baseline model specifications reported in Table 9 we identify the average treatment effect of the "On the Spot Firm" program over all the years since its introduction. We will now focus on an event study, in which we estimate treatment effects at each year, thus assessing whether the effects vary with the duration of the program and the increase in registration. This also confirms whether the effects are not statistically significant prior to introduction of the

\footnotetext{
${ }^{29}$ These overall effects are the same as those obtained in Table 9 by summing the coefficients on the terms Fem $_{i} \times S_{k, i t} \times$ Spot $_{m t}$ and $S_{k, i t} \times$ Spot $_{m t}$. In Table 9 we can determine directly whether the difference between the effects for male and for female workers is statistically significant, which is the case for all except top-managers.
} 
reform, important for our identification strategy. To that end, we estimate specifications of the form:

$$
\begin{aligned}
\ln w_{i j m k t}= & \alpha+\sum_{l} \beta_{1 l}\left(\text { Fem }_{i} \times S_{k, i t} \times \operatorname{Spot}_{m l}\right)+\beta_{2}\left(\text { Fem }_{i} \times S_{k, i t}\right)+ \\
& \sum_{l} \beta_{3 l}\left(\text { Fem }_{i} \times \operatorname{Spot}_{m l}\right)+\sum_{l} \beta_{4 l}\left(S_{k, i t} \times \operatorname{Spot}_{m l}\right)+ \\
& \sum_{l} \beta_{5 l} \operatorname{Spot}_{m l}+\beta_{6} S_{k, i t}+\gamma X_{i t}^{\prime}+\lambda Z_{j t}^{\prime}+d(.)+\epsilon_{i j m k t}
\end{aligned}
$$

Here, we include interaction terms for each pre-treatment year and for each treatment year. $S_{p o t}{ }_{m l}$ is a set of dummy variables for each lag and lead, $l$, relative to the year of implementation of the reform in municipality $m$. In this specification, each coefficient, on the lags and leads, is estimated relative to the period prior to t-4, and to non-adopters. Figure 6 presents the estimated coefficients of interest, on the Fem $\times S_{k} \times S p o t$ interaction terms, which capture the differential effect of the reform on female pay, as well as the $95 \%$ confidence interval (CI). The dots on the solid line are the estimated coefficients and the two dashed lines are the $95 \%$ confidence bands of the estimates. We report the coefficients and CI for each skill category, as discussed above.

\section{[Figure 6 about here]}

As shown in Figure 6, the coefficients for each year prior to the "On the Spot Firm" program are small, often negative and, importantly, statistically insignificant. This supports our identification, and confirms that there is no evidence of anticipatory effects. After the reform is implemented, we obtain positive and statistically significant coefficients, particularly for middlemanagers and for high- and medium-skilled workers, but not for top-managers, consistent with the results from Table 9. Interestingly, we also find that the effects increase over time with the increase in business registration.

Next, we investigate the effect of increased competition resultant from the business registration reform on the gender pay gap for managerial and non-managerial workers. We estimate a specification similar to equation (4), with the same controls and fixed effects, but instead of the triple interaction terms with the five skill categories, we include an interaction with a dummy variable for whether the worker is in a managerial position. Workers in managerial positions are those in levels 1 ("Top executives") and 2 ("Intermediary executives") in the classification described in Table A.1. Table 10 reports the results. In column (1) we estimate the average gender pay gap for all workers and in column (2) we interact the female dummy with the managerial indicator to estimate the differential gender pay gap for managerial workers. Consistent with previous estimates, the gender pay gap is wider for managers than for non-managers, by 5.8 percentage points. 
[Table 10 about here]

In column (3) we estimate the effect of the "On the Spot Firm" program on the gender pay gap for managerial and non-managerial workers. We include worker fixed effects as well as all other controls and fixed effects, as in Table 9. We find that the triple interaction capturing the differential effect of the reform on female managers' pay is positive and statistically significant, implying a reduction in the managerial gender pay gap. Column (4) reports results with firm-worker match fixed effects. The coefficient on the differential effect of the policy on female managers' pay remains positive, statistically significant and of similar magnitude. The magnitude of the estimates implies that while male managers' pay increased overall by $3 \%$ following the reform, female managers' pay increased by $3.5 \%$ and the difference is statistically significant (see also Table A.5). These results show that the reform contributed to narrow the pay gap between male and female managerial workers. Higher demand for managers following the increased firm entry with an inelastic supply of managers is a potential explanation for the increase in overall managerial wage.

In Table 11, we estimate the effect of the reform on the gender pay differential across the corporate hierarchy, using occupations to look at a finer classification of managerial positions. We obtain estimates for the impact on "Directors and Chief Executives" (ISCO88 category 121; CEOs for short), "Department Managers" (ISCO88 categories 122 and 123; DM for short) and other workers in the corporation. We estimate equation (4) but where $S_{k, i t}$ is now a vector of indicator variables for whether the worker is a CEO, a DM or other (the omitted category). The results in columns (1) and (2), for the gender pay gap, remain similar to previous tables.

In column (3), the estimates of the triple interactions of main interest show that while the reform reduced the gender pay gap for department managers, the differential effect on female CEOs' pay, relative to males', is not statistically significant. This is consistent with the results from Table 9, showing that the reform had no statistically significant effect on the gender pay gap for top-managers. Results with match fixed effects, presented in column (4), remain robust. Existing evidence documents the relative absence of females from the top executive job. Our results show that females that break the "glass ceiling" and reach the top of a corporation still have lower pay than their male counterparts, and increased product market competition does not improve their relative pay. This suggests that the labor market for Chief Executives still especially favors men. We also find that the reform has a positive and statistically significant effect on CEOs' and department managers' pay in treated municipalities. The Fem $\times$ CEO term is negative and statistically significant, showing that females that are promoted to the CEO position have a lower pay increase than their male counterparts.

[Table 11 about here] 
Overall, our results in this section provide empirical support for the prediction that increased competition reduces the gender pay gap; but the reduction in the gender pay gap is observed for those in high- and medium-skill occupations and in middle-managerial positions and is not observed for top-executives or for unskilled workers.

\section{Conclusion}

In this paper, we investigate empirically the dynamic implication from Becker's (1957) theory that increased product market competition reduces gender discrimination. Discriminatory employers hire fewer women and more men than profit maximization would imply. Males are paid more than females with the same skills and productivity, and thus employers give up profits to indulge their discriminatory tastes. Since discrimination increases costs, it becomes hard to sustain in a competitive market. Increased competition forces discriminatory employers to change their behavior, reducing the wage differential between male and female workers. Increased product market competition therefore reduces gender discrimination.

We exploit the "On the Spot Firm", a comprehensive business registration reform introduced in Portugal from 2005, as a quasi-natural experiment, which exogenously increased product market competition. Prior to 2005, to register a new business entrepreneurs would need to fulfil 11 procedures in a process that took on average 78 days and cost $13.5 \%$ of GDP per capita. The "On the Spot Firm" reform was introduced with the objective of cutting red tape, reducing the time, cost and complexity of registering a new firm. The program established one-stop shops where entrepreneurs can register a company in a single office desk in less than a hour at a cost of around 3\% of GDP per capita. The program was initially introduced in a few municipalities and was progressively rolled-out randomly across municipalities over time. The program was very successful, and as a result Portugal rose from 113th to 26th in the World Bank "Ease of Doing Business" ranking of countries.

We use matched employer-employee data for the universe of private sector firms and workers in Portugal to investigate the effect of the increased competition following the reform on the relationship between discrimination and firm survival and growth, growth of the female employment share and on the pay differential between men and women. We exploit the crossmunicipality-year variation in the implementation of the program for identification. In addition to unusually detailed observable worker and firm characteristics, such as education, skill level, occupation, we control for worker or worker-firm fixed effects and thus identify the impact of the reform accounting for unobserved worker characteristics or from individuals who stay in the same firm after the reform.

We show that the business registration reform increased firm entry significantly within industries and municipalities, thus contributing to increase competition. We then investigate the 
effects of the reform on gender discrimination. We find that non-discriminatory employers, proxied by a larger female employment share, increase overall employment growth after the reform, while discriminatory employers grow less over time and are more likely to exit the market. We also find that the reform is associated with increased growth in the female employment share, particularly in managerial and high-skill occupations. This suggests that increased competition following the reform induced firms to increase demand for female labor.

We estimate the effect of the reform on the gender pay gap, for workers in different skill categories and across the corporate hierarchy. We find that the entry reform reduced the gender pay gap for middle-managers, high-skilled and medium-skilled workers in affected municipalities. The differential effect of the reform on female workers' pay in treatment municipalities is positive and statistically significant. Our estimates imply that the gender pay gap is reduced by 1.7 percentage points for middle-managers and high-skilled workers and by 1 percentage point for medium-skilled workers. The magnitude of these estimates is equivalent to a reduction in the gender pay gap by $15 \%$ and $13 \%$ for middle-managers and high-skilled workers, respectively, and by $7.6 \%$ for medium-skilled workers, relative to the overall gender pay gap for those categories. The effects on the gender pay gap are not found for unskilled workers or for CEOs. The labor market for the top executive still especially favors men and increased competition does not improve females' relative pay.

Our findings are consistent with the prediction from Becker (1957) that product market competition reduces employer discrimination. Increased competition leads to a higher efficiency loss from discriminating against women, inducing surviving discriminatory firms to change their behavior. Our results have important policy implications. Discrimination has been shown to create inefficiencies that contribute to significantly reduce output across countries (e.g. Cavalcanti and Tavares, 2016). Our findings that reducing entry barriers in Portugal contributes to reduce gender discrimination, particularly the gender pay gap among skilled and managerial workers, suggest that deregulation contributes to reduce inefficiencies arising from gender discrimination. 


\section{References}

1. Aghion, P., R. Blundell, R. Griffith, P. Howitt and S. Prantl (2009). "The effects of entry on incumbent innovation and productivity." Review of Economics and Statistics, 91(1), $20-32$.

2. Albrecht, J., A. Björklund and S. Vroman (2003). "Is There a Glass Ceiling in Sweden?" Journal of Labor Economics 21, 145-177.

3. Arrow, K. J. (1973). "The theory of discrimination." In Orley C. Ashenfelter and Albert Rees (Eds.), Discrimination in Labor Markets. Princeton, NJ: Princeton University Press.

4. Arulampalam, W., A. Booth and M. Bryan (2007). "Is There a Glass Ceiling over Europe? Exploring the Gender Pay Gap across the Wage Distribution." Industrial and Labor Relations Review, 60, 163-186.

5. Ashenfelter, O., T. Hannan (1986). "Sex discrimination and product market competition: The case of the banking industry." The Quarterly Journal of Economics, 101(1), 149-174.

6. Bayard, K., J. Hellerstein, D. Neumark, and K. Troske (2003). "New evidence on sex segregation and sex differences in wages from matched employer-employee data." Journal of Labor Economics, 21, 887-922.

7. Becker, G. (1957). "The economics of discrimination." University of Chicago Press.

8. Bergin, P. and Lin,C. (2012). "The dynamic effects of a currency union on trade." Journal of International Economics,87, 191-204.

9. Black, S. and E. Brainerd (2004). "Importing equality? The impact of globalization on gender discrimination.” Industrial Relations and Labor Review, 57, 540-559.

10. Black, S. and P. Strahan (2001). "The division of spoils: Rent-sharing and discrimination in a regulated industry." American Economic Review, 91(4), 814-831.

11. Blau, F. and L. Kahn (2000). "Gender differences in pay." Journal of Economic Perspectives $14(4), 75-99$.

12. Blau, F. and L. Kahn (2016). "The gender wage gap: Extent, trends, and explanations." Journal of Economic Literature, forthcoming.

13. Borjas, G., and V. Ramey (1995). "Foreign Competition, Market Power, and Wage Inequality." Quarterly Journal of Economics, 110(4), 1075-1110. 
14. Branstetter L., Lima F., Taylor L., Venancio A. 2014. "Do entry regulations deter entrepreneurship and job creation? Evidence from recent reforms in Portugal." Economic Journal 124, 805-832.

15. Bruhn, M. (2011). "License to sell: the effect of business registration reform on entrepreneurial activity in Mexico" The Review of Economics and Statistics, 93, 382-386.

16. Cavalcanti, T. and J. Tavares (2016). "The output cost of discrimination: A model-based macroeconomic estimate.” Economic Journal, 126(590), 109-134.

17. Cuberes, D., M. Teignier (2016). "Aggregate effects of gender gaps in the labor market: A quantitative estimate," Journal of Human Capital, 10(1), 1-32.

18. Djankov, S., C. McLiesh, and R. Ramalho (2006). "Regulation and growth." Economics Letters, 92(3), 395-401.

19. Fernandes A. P., Ferreira P., Winters L. A. 2014. "Firm entry deregulation, competition and returns to education and skill." European Economic Review 70, 210-230.

20. Fernandes A. P., Ferreira P., Winters L. A. 2018. "The effect of competition on executive compensation and incentives: Evidence from a quasi-natural experiment." Journal of Human Resources, 53(3), 783-824.

21. Goldin, C. (2014). "A grand gender convergence: Its last chapter." American Economic Review, 104(4), 1091-1119.

22. Guadalupe, M. (2007). "Product market competition, returns to skill and wage inequality." Journal of Labor Economics, 25(3), 439-474.

23. Hausmann, R., L. Tyson, and S. Zahidi (2006). "The global gender gap report 2006", World Economic Forum, Geneva, Switzerland.

24. Hellerstein, J., D. Neumark, K. Troske (2002). "Market forces and sex discrimination." The Journal of Human Resources, 37(2), 353-380.

25. Heyman, F., H. Svaleryd, and J. Vlachos (2013). "Competition, takeovers, and gender discrimination." Industrial and Labor Relations Review 66(2), 409-432.

26. Kawaguchi, D. (2007). "A market test for sex discrimination: Evidence from Japanese firm-level panel data." International Journal of Industrial Organization, 25, 441-460.

27. List, J. (2004). "The nature and extent of discrimination in the marketplace: Evidence from the field." Quarterly Journal of Economics, 119, 49-89. 
28. Moro, A. (2003). "The effect of statistical discrimination on black-white wage inequality: estimating a model with multiple equilibria." International Economic Review, 44, 2, 467500.

29. Moro, A. and P. Norman (2004). "A general equilibrium model of statistical discrimination." Journal of Economic Theory, 114, 1-30.

30. Phelps, E. S. (1972). "The statistical theory of racism and sexism." American Economic Review 62(4), 659-61.

31. Weber, A. and C. Zulehner (2014). "Competition and gender prejudice: Are discriminatory employers doomed to fail?" Journal of the European Economic Association, 12(2), 492-521.

32. Weichselbaumer, D. and R. Winter-Ebmer (2007). "The effect of competition and equal treatment laws on the gender wage differential." Economic Policy, 22, 237-287.

33. Schmidt K. M. (1997). "Managerial incentives and product market competition." Review of Economic Studies, 64(2), 191-213.

34. Sutton, J. (1991). "Sunk costs and market structure: Price competition, advertising and the evolution of concentration." MIT Press, Cambridge Mass. 


\section{Tables}

Table 1: Sample size

\begin{tabular}{|c|c|c|c|c|}
\hline Year & All firms & Entrants & $\begin{array}{c}\% \text { Entrants } \\
\text { "On the Spot" } \\
(3)\end{array}$ & Workers \\
\hline 2002 & 211,113 & 13,389 & & $1,796,261$ \\
\hline 2003 & 215,354 & 15,603 & & $1,756,603$ \\
\hline 2004 & 218,817 & 14,593 & & $1,790,370$ \\
\hline 2005 & 233,514 & 16,509 & 20.01 & $1,925,115$ \\
\hline 2006 & 235,094 & 17,147 & 42.32 & $1,933,797$ \\
\hline 2007 & 255,757 & 20,182 & 51.24 & $2,050,843$ \\
\hline 2008 & 258,943 & 20,413 & 66.42 & $2,085,363$ \\
\hline 2009 & 253,148 & 17,382 & 76.26 & $2,002,222$ \\
\hline
\end{tabular}

Own calculations based on Portugal, MTSS (2002-2009). 
Table 2: Detailed summary statistics of logged hourly real wage, by group of workers and gender

\begin{tabular}{|c|c|c|c|c|c|c|}
\hline $\ln$ (hourly real pay) & Mean & Median & Std. Dev. & $\mathrm{P} 10$ & $\mathrm{P} 90$ & Nb. Obs. \\
\hline \multicolumn{7}{|l|}{ Skill levels } \\
\hline Top management & 2.351 & 2.351 & 0.728 & 1.368 & 3.286 & 552,936 \\
\hline Males & 2.435 & 2.473 & 0.754 & 1.388 & 3.382 & 360,812 \\
\hline Females & 2.193 & 2.174 & 0.647 & 1.337 & 3.035 & 192,124 \\
\hline Middle management & 1.955 & 1.918 & 0.544 & 1.288 & 2.684 & 972,327 \\
\hline Males & 1.979 & 1.936 & 0.548 & 1.312 & 2.716 & 670,380 \\
\hline Females & 1.901 & 1.876 & 0.532 & 1.238 & 2.599 & 301,947 \\
\hline High skill & 1.866 & 1.850 & 0.513 & 1.204 & 2.531 & 740,749 \\
\hline Males & 1.912 & 1.900 & 0.528 & 1.230 & 2.597 & 415,688 \\
\hline Females & 1.807 & 1.789 & 0.487 & 1.172 & 2.433 & 325,061 \\
\hline Medium skill & 1.383 & 1.318 & 0.371 & 0.975 & 1.872 & $5,277,133$ \\
\hline Males & 1.445 & 1.377 & 0.374 & 1.033 & 1.939 & $3,242,480$ \\
\hline Females & 1.285 & 1.214 & 0.344 & 0.930 & 1.737 & $2,034,653$ \\
\hline Low skill & 1.198 & 1.138 & 0.293 & 0.886 & 1.572 & $4,341,500$ \\
\hline Males & 1.272 & 1.213 & 0.324 & 0.904 & 1.701 & $1,856,241$ \\
\hline Females & 1.143 & 1.095 & 0.253 & 0.881 & 1.456 & $2,485,259$ \\
\hline \multicolumn{7}{|l|}{ Executives } \\
\hline CEOs & 3.020 & 3.064 & 0.783 & 1.956 & 4.007 & 21,422 \\
\hline Males & 3.112 & 3.177 & 0.764 & 2.073 & 4.052 & 17,265 \\
\hline Females & 2.638 & 2.585 & 0.741 & 1.712 & 3.604 & 4,157 \\
\hline Department managers & 2.539 & 2.563 & 0.725 & 1.549 & 3.453 & 189,944 \\
\hline Males & 2.602 & 2.642 & 0.732 & 1.583 & 3.514 & 137,652 \\
\hline Females & 2.373 & 2.373 & 0.679 & 1.473 & 3.245 & 52,292 \\
\hline Other workers & 1.417 & 1.299 & 0.471 & 0.947 & 2.074 & $11,673,279$ \\
\hline Males & 1.508 & 1.394 & 0.488 & 1.003 & 2.184 & $6,390,684$ \\
\hline Females & 1.307 & 1.185 & 0.425 & 0.908 & 1.890 & $5,282,595$ \\
\hline \multicolumn{7}{|l|}{ Managerial } \\
\hline Managerial & 2.236 & 2.215 & 0.679 & 1.346 & 3.122 & 992,382 \\
\hline Males & 2.295 & 2.289 & 0.711 & 1.347 & 3.217 & 638,589 \\
\hline Females & 2.129 & 2.112 & 0.601 & 1.342 & 2.915 & 353,793 \\
\hline Non-managerial & 1.365 & 1.273 & 0.412 & 0.941 & 1.930 & $10,892,263$ \\
\hline Males & 1.453 & 1.364 & 0.427 & 0.993 & 2.041 & $5,907,012$ \\
\hline Females & 1.261 & 1.164 & 0.367 & 0.905 & 1.739 & $4,985,251$ \\
\hline All workers & 1.437 & 1.307 & 0.502 & 0.949 & 2.129 & $11,884,645$ \\
\hline Males & 1.535 & 1.406 & 0.526 & 1.006 & 2.254 & $6,545,601$ \\
\hline Females & 1.318 & 1.189 & 0.443 & 0.909 & 1.925 & $5,339,044$ \\
\hline
\end{tabular}

Own calculations based on Portugal, MTSS (2002-2009). These statistics are computed using the estimation sample. 
Table 3: Pre-reform average growth rates of outcome variables

\begin{tabular}{|c|c|c|c|c|}
\hline & $\begin{array}{c}\text { Late adopters } \\
\text { (1) }\end{array}$ & $\begin{array}{c}\text { Early adopters } \\
(2)\end{array}$ & $\begin{array}{c}\text { Difference } \\
(3)\end{array}$ & $\begin{array}{c}\text { P-value } \\
(4)\end{array}$ \\
\hline \multicolumn{5}{|l|}{ ln Compensation } \\
\hline \multicolumn{5}{|l|}{ Skill levels } \\
\hline Top management & $\begin{array}{c}0.037 \\
(0.006)\end{array}$ & $\begin{array}{c}0.042 \\
(0.010)\end{array}$ & $\begin{array}{l}-0.004 \\
(0.012)\end{array}$ & 0.723 \\
\hline Middle management & $\begin{array}{l}0.026 \\
(0.004)\end{array}$ & $\begin{array}{l}0.034 \\
(0.005)\end{array}$ & $\begin{array}{l}-0.008 \\
(0.008)\end{array}$ & 0.308 \\
\hline High-skill & $\begin{array}{c}0.022 \\
(0.005)\end{array}$ & $\begin{array}{c}0.033 \\
(0.005)\end{array}$ & $\begin{array}{l}-0.010 \\
(0.009)\end{array}$ & 0.230 \\
\hline Medium-skill & $\begin{array}{c}0.015 \\
(0.003)\end{array}$ & $\begin{array}{c}0.019 \\
(0.002)\end{array}$ & $\begin{array}{l}-0.004 \\
(0.005)\end{array}$ & 0.431 \\
\hline Low-skill & $\begin{array}{c}0.014 \\
(0.003)\end{array}$ & $\begin{array}{c}0.016 \\
(0.003)\end{array}$ & $\begin{array}{l}-0.002 \\
(0.005)\end{array}$ & 0.704 \\
\hline \multicolumn{5}{|l|}{ Executives } \\
\hline CEOs & $\begin{array}{c}0.050 \\
(0.020)\end{array}$ & $\begin{array}{c}0.038 \\
(0.017)\end{array}$ & $\begin{array}{c}0.012 \\
(0.030)\end{array}$ & 0.694 \\
\hline Department managers & $\begin{array}{c}0.031 \\
(0.010)\end{array}$ & $\begin{array}{c}0.057 \\
(0.010)\end{array}$ & $\begin{array}{l}-0.026 \\
(0.016)\end{array}$ & 0.114 \\
\hline Other workers & $\begin{array}{c}0.018 \\
(0.002)\end{array}$ & $\begin{array}{c}0.022 \\
(0.002)\end{array}$ & $\begin{array}{l}-0.004 \\
(0.004)\end{array}$ & 0.292 \\
\hline \multicolumn{5}{|l|}{ Managerial work } \\
\hline Managerial & $\begin{array}{c}0.032 \\
(0.006)\end{array}$ & $\begin{array}{c}0.046 \\
(0.009)\end{array}$ & $\begin{array}{l}-0.014 \\
(0.011)\end{array}$ & 0.223 \\
\hline Non-managerial & $\begin{array}{c}0.017 \\
(0.002)\end{array}$ & $\begin{array}{c}0.021 \\
(0.002)\end{array}$ & $\begin{array}{l}-0.004 \\
(0.004)\end{array}$ & 0.352 \\
\hline Gender pay gap & $\begin{array}{l}-0.143 \\
(0.003)\end{array}$ & $\begin{array}{l}-0.136 \\
(0.006)\end{array}$ & $\begin{array}{l}-0.007 \\
(0.006)\end{array}$ & 0.257 \\
\hline Firm entry & $\begin{array}{c}0.155 \\
(0.046)\end{array}$ & $\begin{array}{c}0.114 \\
(0.030)\end{array}$ & $\begin{array}{c}0.040 \\
(0.080)\end{array}$ & 0.615 \\
\hline Employment growth & $\begin{array}{c}0.031 \\
(0.002)\end{array}$ & $\begin{array}{c}0.031 \\
(0.002)\end{array}$ & $\begin{array}{l}-0.000 \\
(0.003)\end{array}$ & 0.970 \\
\hline \multicolumn{5}{|c|}{ Female employment share growth } \\
\hline Managerial & $\begin{array}{c}0.119 \\
(0.037)\end{array}$ & $\begin{array}{c}0.041 \\
(0.026)\end{array}$ & $\begin{array}{c}0.078 \\
(0.064)\end{array}$ & 0.230 \\
\hline High-skill & $\begin{array}{c}0.130 \\
(0.030)\end{array}$ & $\begin{array}{l}0.094 \\
(0.017)\end{array}$ & $\begin{array}{c}0.036 \\
(0.051)\end{array}$ & 0.484 \\
\hline Medium-skill & $\begin{array}{l}-0.008 \\
(0.013)\end{array}$ & $\begin{array}{l}-0.007 \\
(0.011)\end{array}$ & $\begin{array}{l}-0.001 \\
(0.024)\end{array}$ & 0.952 \\
\hline Low-skill & $\begin{array}{l}-0.007 \\
(0.012)\end{array}$ & $\begin{array}{l}-0.011 \\
(0.010)\end{array}$ & $\begin{array}{c}0.004 \\
(0.022)\end{array}$ & 0.869 \\
\hline
\end{tabular}

The table reports initial growth trends (between 2002 and 2004) of average wages, firm entry, employment growth and female employment share growth. For the gender pay gap, we report the coefficient of a female dummy from compensation regressions, for early and for late adopters, over the pre-reform period; we include the same controls as in column (1) of Table 8. Standard errors are reported in parentheses. The p-value is for the test of the null hypothesis of equality between the means (proportions). 
Table 4: Effect of the "On the Spot Firm" program on firm entry

\begin{tabular}{lcccc}
\hline \hline Dependent variable: & \multicolumn{2}{c}{ New firms } & \multicolumn{2}{c}{ New firms } \\
& $(1)$ & $(2)$ & $(3)$ & $(4)$ \\
\hline \multirow{3}{*}{ Stop } & & & & \\
& $0.474^{* * *}$ & $0.430^{* * *}$ & $0.007^{* *}$ & $0.009^{* * *}$ \\
& $(0.133)$ & $(0.133)$ & $(0.003)$ & $(0.003)$ \\
Constant & $1.558^{* * *}$ & $2.122^{* * *}$ & $0.069^{* * *}$ & $0.061^{* * *}$ \\
& $(0.108)$ & $(0.113)$ & $(0.002)$ & $(0.004)$ \\
& & & & \\
\hline Municipality FE & Yes & Yes & Yes & Yes \\
Industry FE & & Yes & & Yes \\
Year FE & Yes & Yes & Yes & Yes \\
\hline R & 0.126 & 0.343 & 0.014 & 0.068 \\
No. Obs. & 56,782 & 56,782 & 55,784 & 55,784 \\
\hline
\end{tabular}

The dependent variable in columns (1) and (2) is the number of new firms and in columns (3) and (4) the ratio of new firms to incumbents. Observations are by municipality-industry-year. We report results from OLS estimation. Robust standard errors, clustered by municipality are reported in parentheses. ${ }^{*} \mathrm{p}<0.10,{ }^{* *}$ $\mathrm{p}<0.05,{ }^{* * *} \mathrm{p}<0.01$ 
Table 5: Effect of the "On the Spot Firm" program and female share on firm growth

\begin{tabular}{lcccc}
\hline \hline Panel A & \multicolumn{4}{c}{ Employment growth } \\
\hline Dependent variable: & \multicolumn{5}{c}{ Femshare $t-1^{2}$} & \multicolumn{2}{c}{ Femshare $_{\text {pre-spot }}$} \\
Female share: & $(1)$ & $(2)$ & $(3)$ & $(4)$ \\
\hline \multirow{3}{*}{ Femshare $\times$ Stop } & $0.004^{*}$ & $0.013^{* * *}$ & $0.008^{* * *}$ & $0.011^{* * *}$ \\
& $(0.002)$ & $(0.003)$ & $(0.002)$ & $(0.003)$ \\
Stop & 0.001 & $-0.005^{* *}$ & $-0.008^{* * *}$ & $-0.013^{* * *}$ \\
& $(0.002)$ & $(0.002)$ & $(0.002)$ & $(0.002)$ \\
Femshare & $-0.009^{* * *}$ & $-0.011^{* *}$ & $-0.009^{* * *}$ & \\
& $(0.001)$ & $(0.005)$ & $(0.001)$ & \\
Constant & $-0.011^{* * *}$ & 0.002 & $0.005^{*}$ & $-0.005^{* * *}$ \\
& $(0.002)$ & $(0.003)$ & $(0.003)$ & $(0.002)$
\end{tabular}

\begin{tabular}{lcccc}
\hline Year FE & Yes & Yes & Yes & Yes \\
Municipality FE & Yes & & Yes & \\
Industry FE & Yes & & Yes & \\
Firm FE & & Yes & & Yes \\
\hline $\mathrm{R}^{2}$ & 0.006 & 0.010 & 0.008 & 0.010 \\
No. Obs & $1,081,868$ & $1,081,868$ & 647,249 & 647,249 \\
\hline
\end{tabular}

\begin{tabular}{lcccc}
\hline Panel B & \multicolumn{4}{c}{ Employment growth } \\
\hline Dependent variable: & \multicolumn{4}{c}{ Femshare pre-spot } \\
Female share & Femshare $t-1$ & $(2)$ & $(3)$ & $(4)$ \\
\hline
\end{tabular}

\begin{tabular}{lcccc} 
Femshare Stop & 0.008 & $0.027^{* * *}$ & $0.019^{* * *}$ & $0.023^{* * *}$ \\
& $(0.006)$ & $(0.007)$ & $(0.005)$ & $(0.006)$ \\
Stop & 0.000 & $-0.010^{* *}$ & $-0.013^{* * *}$ & $-0.020^{* * *}$ \\
& $(0.004)$ & $(0.004)$ & $(0.004)$ & $(0.004)$ \\
Femshare & $-0.008^{* *}$ & $0.054^{* * *}$ & $-0.020^{* * *}$ & \\
& $(0.004)$ & $(0.017)$ & $(0.004)$ & \\
Constant & -0.003 & $-0.021^{* * *}$ & $0.018^{* * *}$ & -0.000 \\
& $(0.005)$ & $(0.008)$ & $(0.004)$ & $(0.002)$ \\
& & & & \\
\hline Year FE & Yes & Yes & Yes & Yes \\
Municipality FE & Yes & & Yes & \\
Industry FE & Yes & & Yes & \\
Firm FE & & Yes & & Yes \\
\hline R & & 0.018 & 0.017 & 0.018 \\
No. Obs. & 306,506 & 306,506 & 205,743 & 205,743 \\
\hline
\end{tabular}

The dependent variable is the growth rate (ln difference) in firm employment. Femshare is the discrimination proxy: the share of females in the firm's workforce. Observations are by firm-year. Panel A reports results for the full sample of firms, while Panel B reports results for the sample that excludes very small firms, with less than 10 workers throughout. Additional controls include whether the firm is an exporter, whether it is multi-establishment, and ownership type. Robust standard errors, clustered by municipality, are reported in parentheses. ${ }^{*} \mathrm{p}<0.10,{ }^{* *} \mathrm{p}<0.05$, $* * * \mathrm{p}<0.01$ 
Table 6: Effect of the "On the Spot Firm" program and female share on firm survival Dependent Variable: $\operatorname{Pr}$ (Firm exit)

\begin{tabular}{|c|c|c|c|c|}
\hline & $(1)$ & $(2)$ & (3) & $(4)$ \\
\hline Stop & $\begin{array}{c}0.004 \\
(0.003)\end{array}$ & $\begin{array}{c}0.024^{* * *} \\
(0.004)\end{array}$ & $\begin{array}{c}0.011^{* *} \\
(0.004)\end{array}$ & $\begin{array}{c}0.035^{* * *} \\
(0.005)\end{array}$ \\
\hline Stop $\times$ Femshare & $\begin{array}{l}-0.004 \\
(0.007)\end{array}$ & $\begin{array}{l}-0.003 \\
(0.008)\end{array}$ & & \\
\hline Stop $\times$ Femsh-quartile 2 & & & $\begin{array}{c}-0.012^{* * *} \\
(0.004)\end{array}$ & $\begin{array}{c}-0.019^{* * *} \\
(0.005)\end{array}$ \\
\hline Stop $\times$ Femsh-quartile 3 & & & $\begin{array}{c}-0.016^{* * *} \\
(0.005)\end{array}$ & $\begin{array}{c}-0.023^{* * *} \\
(0.005)\end{array}$ \\
\hline Stop $\times$ Femsh-quartile 4 & & & $\begin{array}{l}-0.005 \\
(0.006)\end{array}$ & $\begin{array}{l}-0.007 \\
(0.007)\end{array}$ \\
\hline Femshare & $\begin{array}{c}0.013^{* * *} \\
(0.003)\end{array}$ & & & \\
\hline Femsh-quartile 2 & & & $\begin{array}{c}0.003^{* *} \\
(0.001)\end{array}$ & \\
\hline Femsh-quartile 3 & & & $\begin{array}{c}0.007 * * * \\
(0.002)\end{array}$ & \\
\hline Femsh-quartile 4 & & & $\begin{array}{c}0.011^{* * *} \\
(0.002)\end{array}$ & \\
\hline Constant & $\begin{array}{c}0.026^{* * *} \\
(0.004)\end{array}$ & $\begin{array}{c}0.303^{* * *} \\
(0.011)\end{array}$ & $\begin{array}{c}0.027^{* * *} \\
(0.004)\end{array}$ & $\begin{array}{c}0.303^{* * *} \\
(0.011)\end{array}$ \\
\hline Year FE & Yes & Yes & Yes & Yes \\
\hline Municipality FE & Yes & & Yes & \\
\hline Industry FE & Yes & & Yes & \\
\hline Firm FE & & Yes & & Yes \\
\hline $\mathrm{R}^{2}$ & 0.043 & 0.094 & 0.043 & 0.094 \\
\hline No. Obs. & 153,374 & 153,374 & 153,374 & 153,374 \\
\hline
\end{tabular}

The dependent variable is the probability of firm exit; it takes the value 1 if the firm exits the market in year $t$ and zero if it survives. Femshare is the discrimination proxy: the share of females in the firm's workforce in the year prior to the introduction of the reform. Femsh-quartile $\mathrm{q}$ are quartile dummies of the female share, taking the value 1 if a firm is in quartile $q$ of the female share distribution and zero otherwise. Observations are by firm-year. The sample excludes very small firms, with less than 10 workers throughout. Additional controls include firm size, whether the firm is an exporter, whether it is multi-establishment, and ownership type. Robust standard errors, clustered by municipality, are reported in parentheses. ${ }^{*} \mathrm{p}<0.10,{ }^{* *} \mathrm{p}<0.05,{ }^{* * *}$ $\mathrm{p}<0.01$ 
Table 7: Effect of the "On the Spot Firm" program on the female employment share growth

\begin{tabular}{|c|c|c|c|c|c|}
\hline \multicolumn{6}{|l|}{ Panel A } \\
\hline \multirow{2}{*}{ Dependent variable: } & \multicolumn{5}{|c|}{ Female share growth } \\
\hline & $\begin{array}{l}\text { All } \\
(1)\end{array}$ & $\begin{array}{c}\text { Managerial } \\
(2)\end{array}$ & $\begin{array}{c}\text { High-skill } \\
(3)\end{array}$ & $\begin{array}{c}\text { Medium-skill } \\
\text { (4) }\end{array}$ & $\begin{array}{c}\text { Low-skill } \\
(5)\end{array}$ \\
\hline Stop & $\begin{array}{c}0.014^{* * * *} \\
(0.005)\end{array}$ & $\begin{array}{c}0.025^{* *} \\
(0.012)\end{array}$ & $\begin{array}{c}0.023^{* * *} \\
(0.009)\end{array}$ & $\begin{array}{l}-0.003 \\
(0.006)\end{array}$ & $\begin{array}{c}0.016^{* *} \\
(0.007)\end{array}$ \\
\hline Constant & $\begin{array}{c}-0.083^{* * *} \\
(0.006)\end{array}$ & $\begin{array}{l}0.043^{*} \\
(0.024)\end{array}$ & $\begin{array}{c}0.050^{* * *} \\
(0.019)\end{array}$ & $\begin{array}{c}-0.132^{* * *} \\
(0.014)\end{array}$ & $\begin{array}{c}-0.024^{* *} \\
(0.009)\end{array}$ \\
\hline Year FE & Yes & Yes & Yes & Yes & Yes \\
\hline Municipality FE & Yes & Yes & Yes & Yes & Yes \\
\hline Industry FE & Yes & Yes & Yes & Yes & Yes \\
\hline $\mathrm{R}^{2}$ & 0.002 & 0.002 & 0.002 & 0.001 & 0.001 \\
\hline No. Obs. & $1,081,868$ & 187,699 & 326,843 & 726,505 & 574,422 \\
\hline \multicolumn{6}{|l|}{ Panel B } \\
\hline \multirow[t]{2}{*}{ Dependent variable: } & \multicolumn{5}{|c|}{ Female share growth } \\
\hline & $\begin{array}{l}\text { All } \\
(1)\end{array}$ & $\begin{array}{l}\text { Managerial } \\
(2)\end{array}$ & $\begin{array}{l}\text { High-skill } \\
(3)\end{array}$ & $\begin{array}{c}\text { Medium-skill } \\
(4)\end{array}$ & $\begin{array}{c}\text { Low-skill } \\
(5)\end{array}$ \\
\hline Stop & $\begin{array}{c}0.015^{* * *} \\
(0.005)\end{array}$ & $\begin{array}{c}0.022 \\
(0.015)\end{array}$ & $\begin{array}{c}0.022^{* *} \\
(0.010)\end{array}$ & $\begin{array}{l}-0.006 \\
(0.007)\end{array}$ & $\begin{array}{l}0.017^{* *} \\
(0.008)\end{array}$ \\
\hline Constant & $\begin{array}{c}-0.690^{* * *} \\
(0.014)\end{array}$ & $\begin{array}{c}-0.542^{* * *} \\
(0.050)\end{array}$ & $\begin{array}{c}-0.592^{* * *} \\
(0.037)\end{array}$ & $\begin{array}{c}-0.521^{* * *} \\
(0.021)\end{array}$ & $\begin{array}{c}-0.554^{* * *} \\
(0.023)\end{array}$ \\
\hline Year FE & Yes & Yes & Yes & Yes & Yes \\
\hline Firm FE & Yes & Yes & Yes & Yes & Yes \\
\hline $\mathrm{R}^{2}$ & 0.009 & 0.002 & 0.004 & 0.003 & 0.003 \\
\hline No. Obs. & $1,081,868$ & 187,699 & 326,843 & 726,505 & 574,422 \\
\hline
\end{tabular}

The dependent variable is the growth rate (ln difference) in the female employment share in each skill category. We use the natural log of the shares plus 0.001 to account for cases in which the share is zero. Observations are by firm-year. Additional controls include the ln of size, whether the firm is an exporter, whether it is multiestablishment and ownership type. Robust standard errors, clustered by municipality, are reported in parenthesis. ${ }^{*} \mathrm{p}<0.10,{ }^{* *} \mathrm{p}<0.05,{ }^{* * *} \mathrm{p}<0.01$ 
Table 8: Overall gender pay gap

\begin{tabular}{lcc}
\hline \hline Dependent variable: & \multicolumn{2}{c}{ ln Compensation } \\
& $(1)$ & $(2)$ \\
\hline & & \\
Female & $0.134^{* * *}$ & $-0.128^{* * *}$ \\
& $(0.002)$ & $(0.002)$ \\
Med-skill & $0.130^{* * *}$ & $0.144^{* * *}$ \\
& $(0.003)$ & $(0.002)$ \\
High-skill & $0.365^{* * *}$ & $0.332^{* * *}$ \\
& $(0.011)$ & $(0.010)$ \\
Mid-manag & $0.476^{* * *}$ & $0.484^{* * *}$ \\
& $(0.006)$ & $(0.006)$ \\
Top-manag & $0.710^{* * *}$ & $0.739^{* * *}$ \\
& $(0.007)$ & $(0.006)$ \\
Isced2 & $0.069^{* * *}$ & $0.049^{* * *}$ \\
& $(0.002)$ & $(0.001)$ \\
Isced3 & $0.148^{* * *}$ & $0.103^{* * *}$ \\
& $(0.004)$ & $(0.003)$ \\
Isced56 & $0.433^{* * *}$ & $0.339^{* * *}$ \\
& $(0.005)$ & $(0.004)$ \\
ln(firm size) & $0.025^{* * *}$ & $0.017^{* * *}$ \\
& $(0.003)$ & $(0.002)$ \\
& & \\
\hline Year FE & Yes & Yes \\
Municipality FE & Yes & \\
Industry FE & Yes & Yes \\
Firm FE & & 0.451 \\
R ${ }^{2}$ & 0.610 & $11,884,645$ \\
No. Obs. & $11,884,645$ & \\
\hline & & \\
The & & \\
& &
\end{tabular}

The dependent variable is the natural log of real hourly wage. ISCED are the educational categories, defined in Section 4.1. Skill categories are also defined in Section 4.1. Other covariates include the worker's tenure and its square, the type of employment contract (whether openended or fixed-term), the instrument of collective regulation, the number of times a worker is promoted, the share of females in the workforce, the share of low-skilled workers in total firm employment, whether the firm is an exporter, whether it is multi-establishment, and ownership. Robust standard errors, clustered by firm, are reported in parentheses. ${ }^{*} \mathrm{p}<0.10 ;{ }^{* *} \mathrm{p}<0.05 ;{ }^{* * *} \mathrm{p}<0.01$. 
Table 9: Effect of the "On the Spot Firm" program on the gender pay gap, by skill levels Dependent variable: $\ln$ Compensation

(1) (2)

$(3)$

(4)

Female

Med-skill $\times$ Female $\times$ Stop

High-skill $\times$ Female $\times$ Stop

Mid-manag $\times$ Female $\times$ Stop

Top-manag $\times$ Female $\times$ Stop

Female $\times$ Stop

Med-skill $\times$ Stop

High-skill $\times$ Stop

Mid-manag $\times$ Stop

Top-manag $\times$ Stop

Stop

Med-skill

High-skill

Mid-manag

Top-manag

Med-skill $\times$ Female

High-skill $\times$ Female

Mid-manag $\times$ Female

Top-manag $\times$ Female

Promotions

Promotions $\times$ Female

$$
\begin{array}{cc}
-0.128^{* * *} & -0.096^{* * *} \\
(0.003) & (0.004)
\end{array}
$$

$0.010^{* *} \quad 0.011^{*}$

(0.005) (0.006)

$0.016^{* * *} \quad 0.017^{* *}$

(0.006) (0.007)

$0.015^{* *} \quad 0.017^{* *}$

(0.006) (0.007)

$0.005 \quad 0.006$

$(0.005) \quad(0.006)$

$-0.004 \quad-0.007$

$(0.004) \quad(0.005)$

$0.003 \quad-0.001$

(0.003) (0.004)

$0.014^{* * *} \quad 0.013^{* * *}$

(0.003) (0.003)

0.026 *** $\quad 0.022^{* * *}$

(0.003) (0.004)

$0.039 * * * \quad 0.033^{* * *}$

(0.005) (0.005)

$-0.005 \quad-0.002$

(0.004) (0.004)

$0.048^{* * *} \quad 0.025^{* * *}$

$\begin{array}{cccc}0.144^{* * *} & 0.167^{* * *} & 0.048^{* * *} & 0.025^{* * *} \\ (0.002) & (0.003) & (0.002) & (0.002)\end{array}$

$0.332^{* * *} \quad 0.352^{* * *} \quad 0.079 * * * \quad 0.036 * * *$

$\begin{array}{llll}(0.005) & (0.007) & (0.003) & (0.002)\end{array}$

$0.484^{* * *} \quad 0.497^{* * *} \quad 0.114^{* * *} \quad 0.061^{* * *}$

$\begin{array}{llll}(0.011) & (0.009) & (0.003) & (0.003)\end{array}$

$0.739^{* * *} \quad 0.788^{* * *} \quad 0.127^{* * *} \quad 0.064^{* * *}$

$\begin{array}{llll}(0.017) & (0.016) & (0.003) & (0.003)\end{array}$

$-0.049^{* * *}-0.024^{* * *} \quad-0.011^{* * *}$

$\begin{array}{lll}(0.007) & (0.002) \quad(0.002)\end{array}$

$-0.040^{* * *} \quad-0.019 * * * \quad-0.009 * *$

$\begin{array}{lll}(0.006) & (0.003) \quad(0.004)\end{array}$

$-0.018^{* *} \quad-0.004 \quad 0.003$

$\begin{array}{lll}(0.008) & (0.003) & (0.003)\end{array}$

$-0.129 * * * \quad-0.013^{* * *} \quad 0.001$

$(0.010) \quad(0.004) \quad(0.004)$
$-0.033^{* * *} \quad\left(0.037^{* * *} \quad 0.036 * *\right.$

$\begin{array}{cccc}-0.033^{* * *} & -0.033^{* * *} & 0.037^{* * *} & 0.036^{* * *} \\ (0.001) & (0.001) & (0.001) & (0.002)\end{array}$

$-0.008^{* * *}-0.007 * *$

$(0.003) \quad(0.003)$

\begin{tabular}{lcccc}
\hline Year FE & Yes & Yes & Yes & Yes \\
$\begin{array}{l}\text { Municipality FE } \\
\text { Industry FE }\end{array}$ & & & Yes & \\
$\begin{array}{l}\text { Firm FE } \\
\text { Worker FE }\end{array}$ & Yes & Yes & Yes & \\
Match (worker-firm) FE & & & Yes & \\
\hline $\mathrm{R}^{2}$ & 0.451 & 0.452 & 0.111 & 0.089 \\
No. Obs. & $11,884,645$ & $11,884,645$ & $11,884,645$ & $11,884,645$ \\
\hline
\end{tabular}

The dependent variable is the natural log of real hourly pay. Skill categories are defined in Section 4.1. Other covariates include the workers' tenure and its square, the level of education, the type of employment contract (whether open-ended or fixed-term), the instrument of collective regulation, the natural log of firm size (number of employees), the share of females in the workforce, the share of low skilled workers in total firm employment, whether the firm is an exporter, whether it is multi-establishment, and ownership type. In columns (3) and (4) all righ-hand side variables are interacted with the female dummy, including the fixed effects. Robust standard errors, clustered by municipality, are reported in parentheses. $* \mathrm{p}<0.10 ; * * \mathrm{p}<0.05 ; * * * \mathrm{p}<0.01$. 
Table 10: Effect of the "On the Spot Firm" program on the gender pay gap, managerial Dependent variable: ln Compensation

$(1)$

$(2)$

$(3)$

$(4)$

\begin{tabular}{|c|c|c|c|c|}
\hline Female & $\begin{array}{c}-0.128^{* * *} \\
(0.003)\end{array}$ & $\begin{array}{c}-0.122^{* * *} \\
(0.003)\end{array}$ & & \\
\hline Manager $\times$ Female $\times$ Stop & & & $\begin{array}{l}0.006^{*} \\
(0.003)\end{array}$ & $\begin{array}{c}0.005^{* *} \\
(0.003)\end{array}$ \\
\hline Female $\times S t o p$ & & & $\begin{array}{c}0.000 \\
(0.001)\end{array}$ & $\begin{array}{l}-0.001 \\
(0.001)\end{array}$ \\
\hline Manager $\times$ Stop & & & $\begin{array}{c}0.034^{* * *} \\
(0.003)\end{array}$ & $\begin{array}{c}0.030^{* * *} \\
(0.004)\end{array}$ \\
\hline Stop & & & $\begin{array}{l}-0.001 \\
(0.002)\end{array}$ & $\begin{array}{l}-0.000 \\
(0.002)\end{array}$ \\
\hline Manager & $\begin{array}{c}0.123^{* * *} \\
(0.005)\end{array}$ & $\begin{array}{c}0.142^{* * *} \\
(0.006)\end{array}$ & $\begin{array}{l}-0.004 \\
(0.003)\end{array}$ & $\begin{array}{c}-0.007^{* *} \\
(0.003)\end{array}$ \\
\hline Manager $\times$ Female & & $\begin{array}{c}-0.058^{* * *} \\
(0.006)\end{array}$ & $\begin{array}{l}-0.007 \\
(0.007)\end{array}$ & $\begin{array}{l}-0.006 \\
(0.008)\end{array}$ \\
\hline Med-skill & $\begin{array}{c}0.144^{* * * *} \\
(0.002)\end{array}$ & $\begin{array}{c}0.145^{* * *} \\
(0.002)\end{array}$ & $\begin{array}{c}0.049^{* * *} \\
(0.001)\end{array}$ & $\begin{array}{c}0.024^{* * *} \\
(0.001)\end{array}$ \\
\hline High-skill & $\begin{array}{c}0.339 * * * \\
(0.005)\end{array}$ & $\begin{array}{c}0.340^{* * *} \\
(0.006)\end{array}$ & $\begin{array}{c}0.085^{* * *} \\
(0.002)\end{array}$ & $\begin{array}{c}0.041^{* * *} \\
(0.002)\end{array}$ \\
\hline Mid-manag & $\begin{array}{c}0.437^{* * * *} \\
(0.009)\end{array}$ & $\begin{array}{c}0.439 * * * \\
(0.009)\end{array}$ & $\begin{array}{c}0.121^{* * *} \\
(0.003)\end{array}$ & $\begin{array}{c}0.068^{* * *} \\
(0.003)\end{array}$ \\
\hline Top-manag & $\begin{array}{c}0.631^{* * *} \\
(0.016)\end{array}$ & $\begin{array}{c}0.632^{* * *} \\
(0.016)\end{array}$ & $\begin{array}{c}0.136^{* * *} \\
(0.003)\end{array}$ & $\begin{array}{c}0.072^{* * *} \\
(0.003)\end{array}$ \\
\hline Med-skill $\times$ Female & & & $\begin{array}{c}-0.020^{* * *} \\
(0.003)\end{array}$ & $\begin{array}{c}-0.008 * * * \\
(0.002)\end{array}$ \\
\hline High-skill $\times$ Female & & & $\begin{array}{c}-0.012^{* * *} \\
(0.003)\end{array}$ & $\begin{array}{l}-0.001 \\
(0.003)\end{array}$ \\
\hline Mid-manag $\times$ Female & & & $\begin{array}{c}0.005 \\
(0.008)\end{array}$ & $\begin{array}{c}0.012 \\
(0.008)\end{array}$ \\
\hline Top-manag $\times$ Female & & & $\begin{array}{l}-0.007 \\
(0.007)\end{array}$ & $\begin{array}{c}0.008 \\
(0.007)\end{array}$ \\
\hline Promotions & $\begin{array}{c}-0.034^{* * *} \\
(0.001)\end{array}$ & $\begin{array}{c}-0.034^{* * *} \\
(0.001)\end{array}$ & $\begin{array}{c}0.036^{* * *} \\
(0.001)\end{array}$ & $\begin{array}{c}0.037^{* * *} \\
(0.002)\end{array}$ \\
\hline Promotions $\times$ Female & & & $\begin{array}{c}-0.007^{* * *} \\
(0.003)\end{array}$ & $\begin{array}{c}-0.007^{* *} \\
(0.003)\end{array}$ \\
\hline Year FE & Yes & Yes & Yes & Yes \\
\hline Municipality FE & & & Yes & \\
\hline Industry FE & & & Yes & \\
\hline Firm FE & Yes & Yes & & \\
\hline Worker FE & & & Yes & \\
\hline Match FE & & & & Yes \\
\hline$\overline{\mathrm{R}^{2}}$ & 0.453 & 0.453 & 0.110 & 0.089 \\
\hline No. Obs & $11,884,645$ & $11,884,645$ & $11,884,645$ & $11,884,645$ \\
\hline
\end{tabular}

The dependent variable is the natural log of real hourly pay. Workers in managerial positions are those in levels 1 ("Top management") or 2 ("Middle management") in the classification described in Table A.1. Other covariates include the workers' tenure and its square, the level of education, the type of employment contract (whether open-ended or fixed-term), the

instrument of collective regulation, the natural log of firm size (number of employees), the share of females in the workforce, the share of low skilled workers in total firm employment, whether the firm is an exporter, whether it is multi-establishment, and ownership type. In columns (3) and (4) all righ-hand side variables are interacted with the female dummy, including the fixed effects. Robust standard errors, clustered by municipality, are reported in parentheses. ${ }^{*} \mathrm{p}<0.10 ; * * \mathrm{p}<0.05 ; * * * \mathrm{p}<0.01$. 
Table 11: Effect of the "On the Spot Firm" program on the gender pay gap, by occupation

\begin{tabular}{|c|c|c|c|c|}
\hline \multirow{2}{*}{ Dependent variable: } & \multicolumn{4}{|c|}{ ln Compensation } \\
\hline & $(1)$ & $(2)$ & $(3)$ & $(4)$ \\
\hline Female & $\begin{array}{c}-0.124^{* * *} \\
(0.003)\end{array}$ & $\begin{array}{c}-0.122^{* * *} \\
(0.003)\end{array}$ & & \\
\hline Dept-Manag $\times$ Female $\times$ Stop & & & $\begin{array}{c}0.018^{* * *} \\
(0.004)\end{array}$ & $\begin{array}{c}0.011^{* * *} \\
(0.004)\end{array}$ \\
\hline $\mathrm{CEO} \times$ Female $\times S t o p$ & & & $\begin{array}{l}-0.003 \\
(0.011)\end{array}$ & $\begin{array}{c}0.005 \\
(0.012)\end{array}$ \\
\hline Female $\times$ Stop & & & $\begin{array}{c}0.000 \\
(0.001)\end{array}$ & $\begin{array}{l}-0.001 \\
(0.001)\end{array}$ \\
\hline Dept-Manag $\times$ Stop & & & $\begin{array}{c}0.033^{* * *} \\
(0.006)\end{array}$ & $\begin{array}{c}0.037^{* * *} \\
(0.005)\end{array}$ \\
\hline $\mathrm{CEO} \times$ Stop & & & $\begin{array}{c}0.045^{* * * *} \\
(0.005)\end{array}$ & $\begin{array}{c}0.038^{* * *} \\
(0.005)\end{array}$ \\
\hline Stop & & & $\begin{array}{c}0.001 \\
(0.002)\end{array}$ & $\begin{array}{c}0.002 \\
(0.002)\end{array}$ \\
\hline Dept-Manag & $\begin{array}{c}0.379^{* * *} \\
(0.008)\end{array}$ & $\begin{array}{c}0.406^{* * *} \\
(0.008)\end{array}$ & $\begin{array}{c}0.074^{* * *} \\
(0.003)\end{array}$ & $\begin{array}{c}0.043^{* * *} \\
(0.003)\end{array}$ \\
\hline $\mathrm{CEO}$ & $\begin{array}{c}0.695^{* * *} \\
(0.018)\end{array}$ & $\begin{array}{c}0.743^{* * *} \\
(0.018)\end{array}$ & $\begin{array}{c}0.121^{* * *} \\
(0.007)\end{array}$ & $\begin{array}{c}0.069^{* * *} \\
(0.007)\end{array}$ \\
\hline Dept-Manag $\times$ Female & & $\begin{array}{c}-0.100^{* * *} \\
(0.006)\end{array}$ & $\begin{array}{c}-0.020^{* * *} \\
(0.004)\end{array}$ & $\begin{array}{c}-0.010^{* *} \\
(0.005)\end{array}$ \\
\hline $\mathrm{CEO} \times$ Female & & $\begin{array}{c}-0.247^{* * *} \\
(0.018)\end{array}$ & $\begin{array}{c}-0.045^{* * *} \\
(0.011)\end{array}$ & $\begin{array}{c}-0.024^{* *} \\
(0.011)\end{array}$ \\
\hline Med-skill & $\begin{array}{c}0.145^{* * *} \\
(0.002)\end{array}$ & $\begin{array}{c}0.145^{* * *} \\
(0.002)\end{array}$ & $\begin{array}{c}0.049^{* * *} \\
(0.001)\end{array}$ & $\begin{array}{c}0.024^{* * *} \\
(0.001)\end{array}$ \\
\hline High-skill & $\begin{array}{c}0.330^{* * *} \\
(0.005)\end{array}$ & $\begin{array}{c}0.330^{* * *} \\
(0.005)\end{array}$ & $\begin{array}{c}0.084^{* * *} \\
(0.003)\end{array}$ & $\begin{array}{c}0.040^{* * *} \\
(0.002)\end{array}$ \\
\hline Mid-manag & $\begin{array}{c}0.465^{* * *} \\
(0.011)\end{array}$ & $\begin{array}{c}0.466^{* * *} \\
(0.011)\end{array}$ & $\begin{array}{c}0.121^{* * *} \\
(0.003)\end{array}$ & $\begin{array}{c}0.067^{* * *} \\
(0.002)\end{array}$ \\
\hline Top-manag & $\begin{array}{c}0.605^{* * *} \\
(0.019)\end{array}$ & $\begin{array}{c}0.606^{* * *} \\
(0.019)\end{array}$ & $\begin{array}{c}0.127^{* * *} \\
(0.003)\end{array}$ & $\begin{array}{c}0.066^{* * *} \\
(0.003)\end{array}$ \\
\hline Med-skill $\times$ Female & & & $\begin{array}{c}-0.020^{* * *} \\
(0.003)\end{array}$ & $\begin{array}{c}-0.007^{* * *} \\
(0.002)\end{array}$ \\
\hline High-skill $\times$ Female & & & $\begin{array}{c}-0.011^{* * *} \\
(0.003)\end{array}$ & $\begin{array}{c}-0.000 \\
(0.003)\end{array}$ \\
\hline Mid-manag $\times$ Female & & & $\begin{array}{c}0.004 \\
(0.005)\end{array}$ & $\begin{array}{c}0.012^{* *} \\
(0.005)\end{array}$ \\
\hline Top-manag $\times$ Female & & & $\begin{array}{l}-0.004 \\
(0.004)\end{array}$ & $\begin{array}{c}0.008^{* *} \\
(0.003)\end{array}$ \\
\hline Promotions & $\begin{array}{c}-0.031^{* * *} \\
(0.001)\end{array}$ & $\begin{array}{c}-0.031^{* * *} \\
(0.001)\end{array}$ & $\begin{array}{c}0.037^{* * *} \\
(0.001)\end{array}$ & $\begin{array}{c}0.037^{* * *} \\
(0.002)\end{array}$ \\
\hline Promotions $\times$ Female & & & $\begin{array}{c}-0.008^{* * *} \\
(0.003)\end{array}$ & $\begin{array}{c}-0.007^{* * *} \\
(0.003)\end{array}$ \\
\hline Municipality FE & & & Yes & \\
\hline Industry FE & & & Yes & \\
\hline Year FE & Yes & Yes & Yes & Yes \\
\hline Firm FE & Yes & Yes & & \\
\hline Worker FE & & & Yes & \\
\hline Match FE & & & & Yes \\
\hline $\mathrm{R}^{2}$ & 0.469 & 0.470 & 0.111 & 0.089 \\
\hline No. Obs. & $11,884,645$ & $11,884,645$ & $11,884,645$ & $11,884,645$ \\
\hline
\end{tabular}

The dependent variable is the natural log of real hourly pay. CEOs are workers whose 3 -digit ISCO 88 occupation is 121 , Department mangers are those in the 3-digit occupations 122 or 123 . Other covariates include the workers' tenure and its square, the level of education, the type of employment contract (whether open-ended or fixed-term), the instrument of collective regulation, the natural log of firm size (number of employees), the share of female workers in total firm employment, the share of low skilled workers in total firm employment, whether the firm is an exporter, whether it is multi-establishment, and ownership. In columns (3) and (4) all righ-hand side variables are interacted with the female dummy, including the fixed effects. Robust standard errors, clustered by municipality, in parentheses. ${ }^{*} \mathrm{p}<0.10 ;{ }^{* *} \mathrm{p}<0.05 ; * * * \mathrm{p}<0.01$. 


\section{Figures}
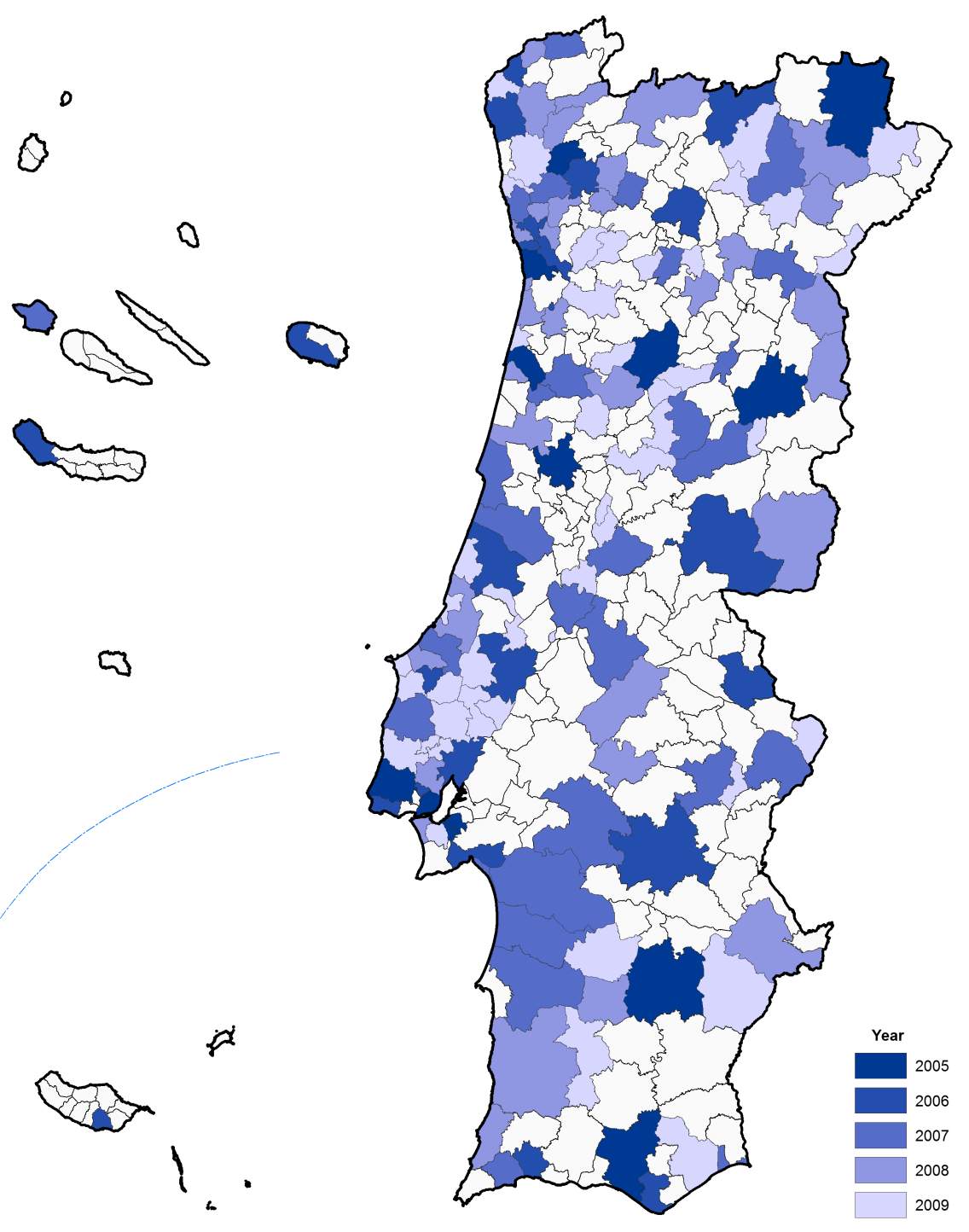

Figure 1: Introduction of the "On the Spot Firm" program by year and municipality 


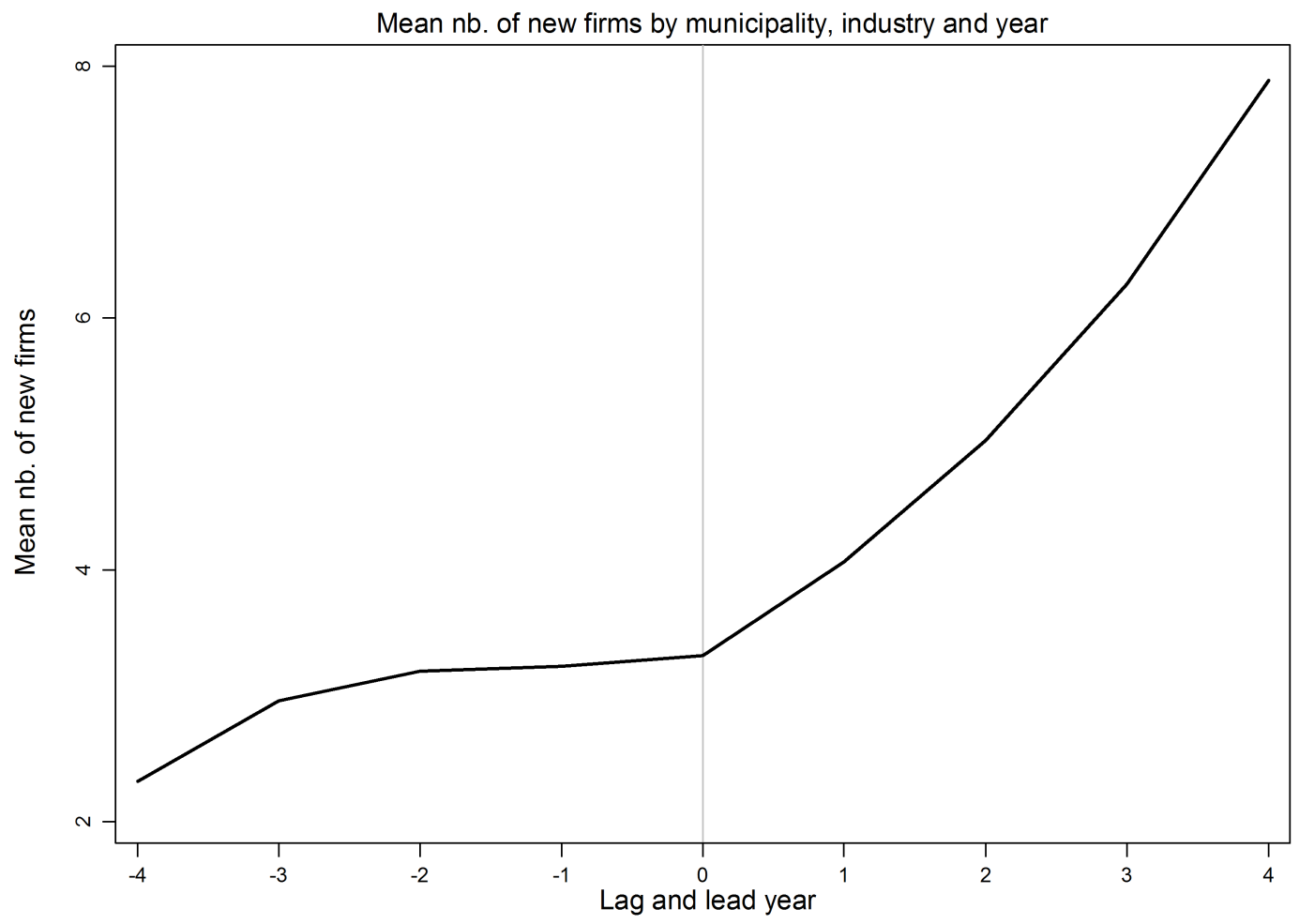

Figure 2: Average number of entrants over time, relative to the year of adoption of the "On the Spot Firm" program 


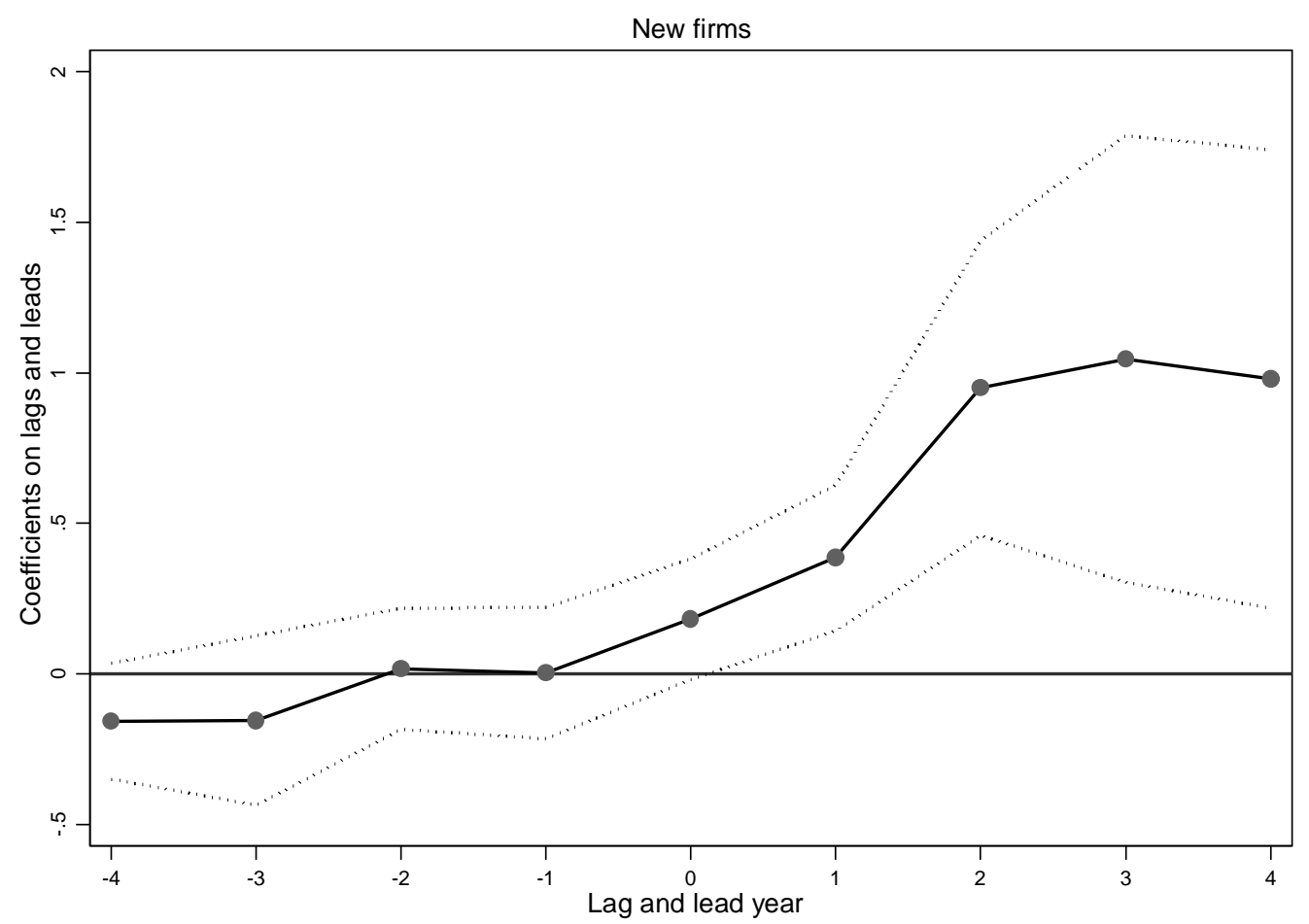

Figure 3: Effect of the "On the Spot Firm" program on firm entry over time 


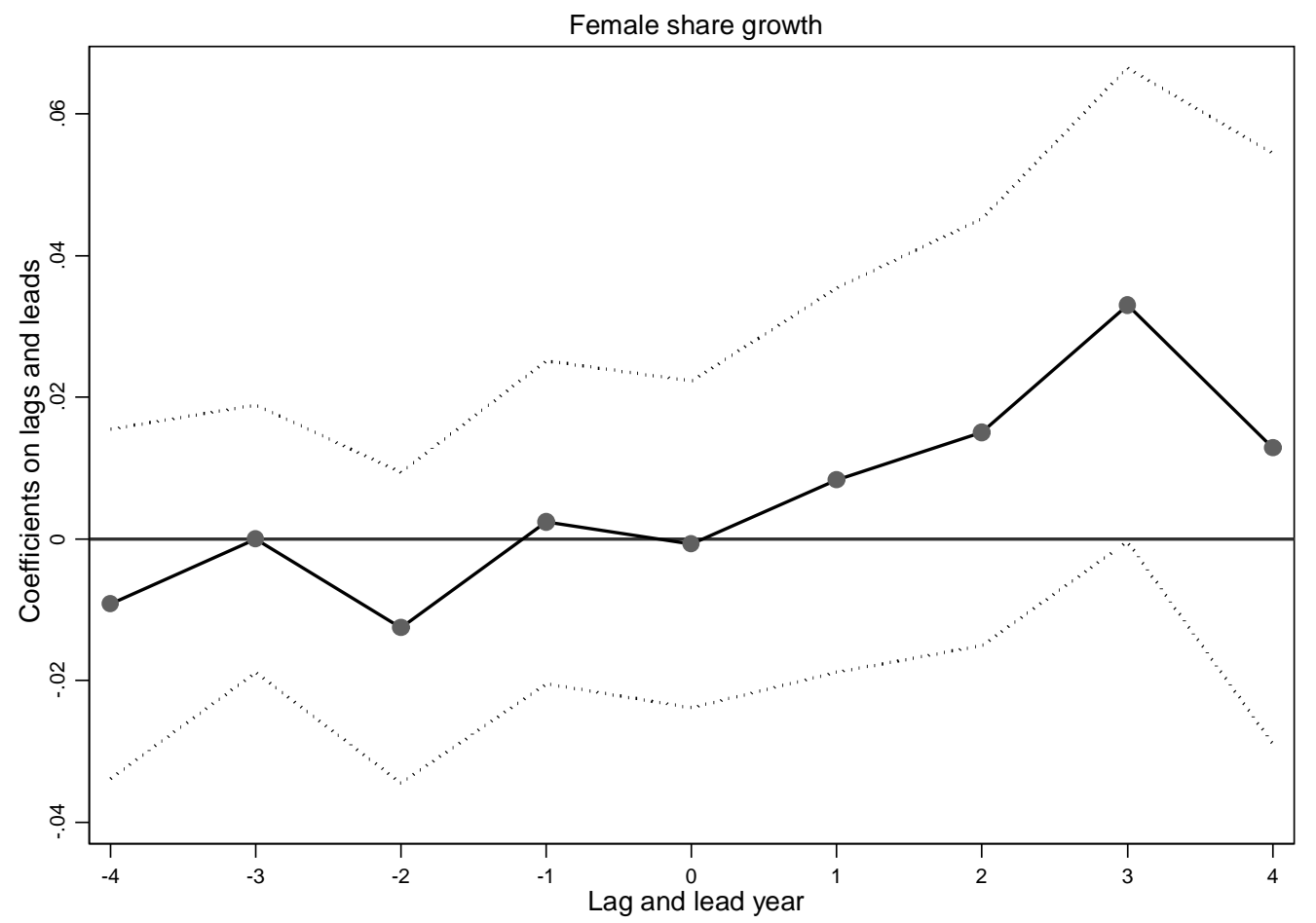

Figure 4: Effect of the "On the Spot Firm" program on female employment share growth over time 

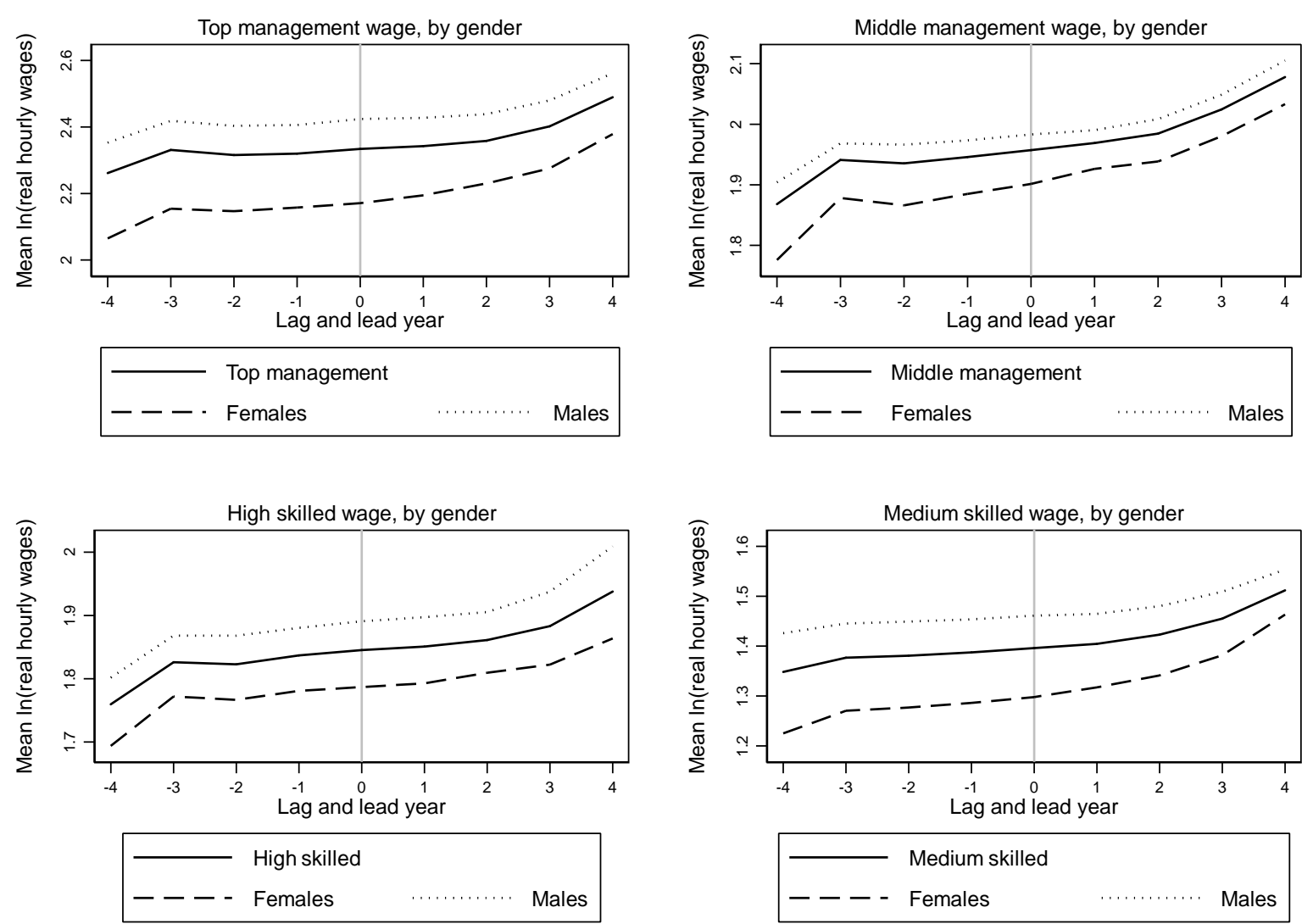

Figure 5: Average wages over time, relative to the year of adoption of the "On the Spot Firm" program 

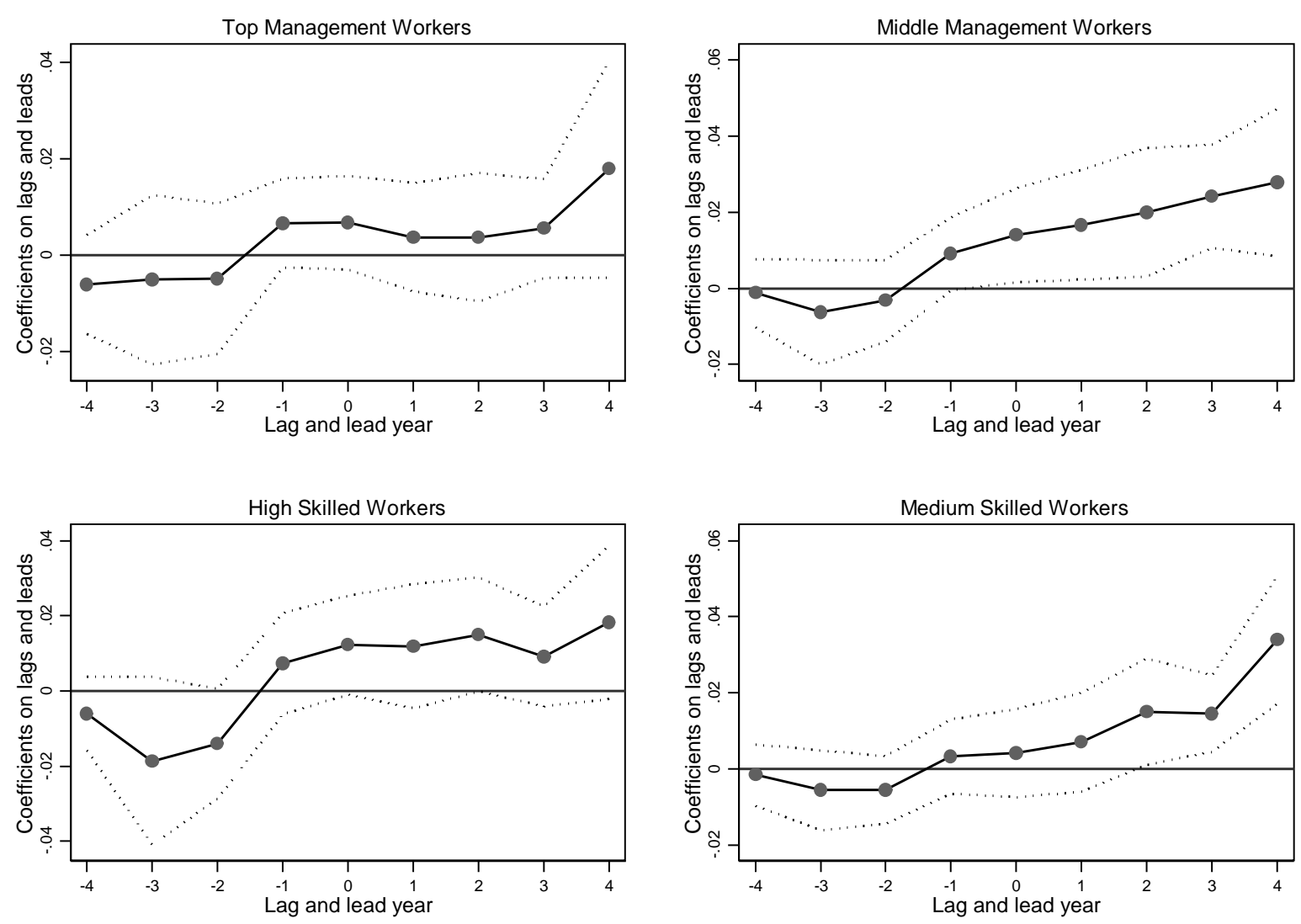

Figure 6: Effect of the "On the Spot Firm" program on the gender pay gap over time 


\section{A Appendix}

Table A.1: Classification of workers according to the skill requirement of the tasks

\begin{tabular}{|c|c|c|}
\hline Level & Tasks & Skills \\
\hline $\begin{array}{l}\text { 1. Top executives (top man- } \\
\text { agement) }\end{array}$ & $\begin{array}{l}\text { Definition of the firm general } \\
\text { policy or consulting on the or- } \\
\text { ganization of the firm; stra- } \\
\text { tegic planning; creation or ad- } \\
\text { aptation of technical, scientific } \\
\text { and administrative methods or } \\
\text { processes }\end{array}$ & $\begin{array}{l}\text { Knowledge of management } \\
\text { and coordination of firms' } \\
\text { fundamental activities; know- } \\
\text { ledge of management and } \\
\text { coordination of the funda- } \\
\text { mental activities in the field } \\
\text { to which the individual is } \\
\text { assigned and that requires the } \\
\text { study and research of high } \\
\text { responsibility and technical } \\
\text { level problems }\end{array}$ \\
\hline $\begin{array}{l}\text { 2. Intermediary executives } \\
\text { (middle management) }\end{array}$ & $\begin{array}{l}\text { Organization and adaptation } \\
\text { of the guidelines established } \\
\text { by the superiors and directly } \\
\text { linked with the executive work }\end{array}$ & $\begin{array}{l}\text { Technical and professional } \\
\text { qualifications directed to } \\
\text { executive, research, and } \\
\text { management work }\end{array}$ \\
\hline 3. Supervisors, team leaders & $\begin{array}{l}\text { Orientation of teams, as direc- } \\
\text { ted by the superiors, but re- } \\
\text { quiring the knowledge of ac- } \\
\text { tion processes }\end{array}$ & $\begin{array}{l}\text { Complete professional qualific- } \\
\text { ation with a specialization }\end{array}$ \\
\hline 4. Higher-skilled professionals & $\begin{array}{l}\text { Tasks requiring a high tech- } \\
\text { nical value and defined in gen- } \\
\text { eral terms by the superiors }\end{array}$ & $\begin{array}{l}\text { Complete professional quali- } \\
\text { fication with a specialization } \\
\text { adding to theoretical and ap- } \\
\text { plied knowledge }\end{array}$ \\
\hline 5. Skilled professionals & $\begin{array}{l}\text { Complex or delicate tasks, } \\
\text { usually not repetitive, and } \\
\text { defined by the superiors }\end{array}$ & $\begin{array}{l}\text { Complete professional qualific- } \\
\text { ation implying theoretical and } \\
\text { applied knowledge }\end{array}$ \\
\hline 6. Semi-skilled professionals & $\begin{array}{l}\text { Well defined tasks, mainly } \\
\text { manual or mechanical (no in- } \\
\text { tellectual work) with low com- } \\
\text { plexity, usually routine and } \\
\text { sometimes repetitive }\end{array}$ & $\begin{array}{l}\text { Professional qualification in a } \\
\text { limited field or practical and } \\
\text { elementary professional know- } \\
\text { ledge }\end{array}$ \\
\hline 7. Non-skilled professionals & $\begin{array}{l}\text { Simple tasks and totally de- } \\
\text { termined }\end{array}$ & $\begin{array}{l}\text { Practical knowledge and easily } \\
\text { acquired in a short time }\end{array}$ \\
\hline $\begin{array}{l}\text { 8. Apprentices, interns, train- } \\
\text { ees }\end{array}$ & Apprenticeship & \\
\hline
\end{tabular}

Hierarchical levels defined according to Decreto Lei 121/78 of July 2nd (Lima and Pereira, 2003). 


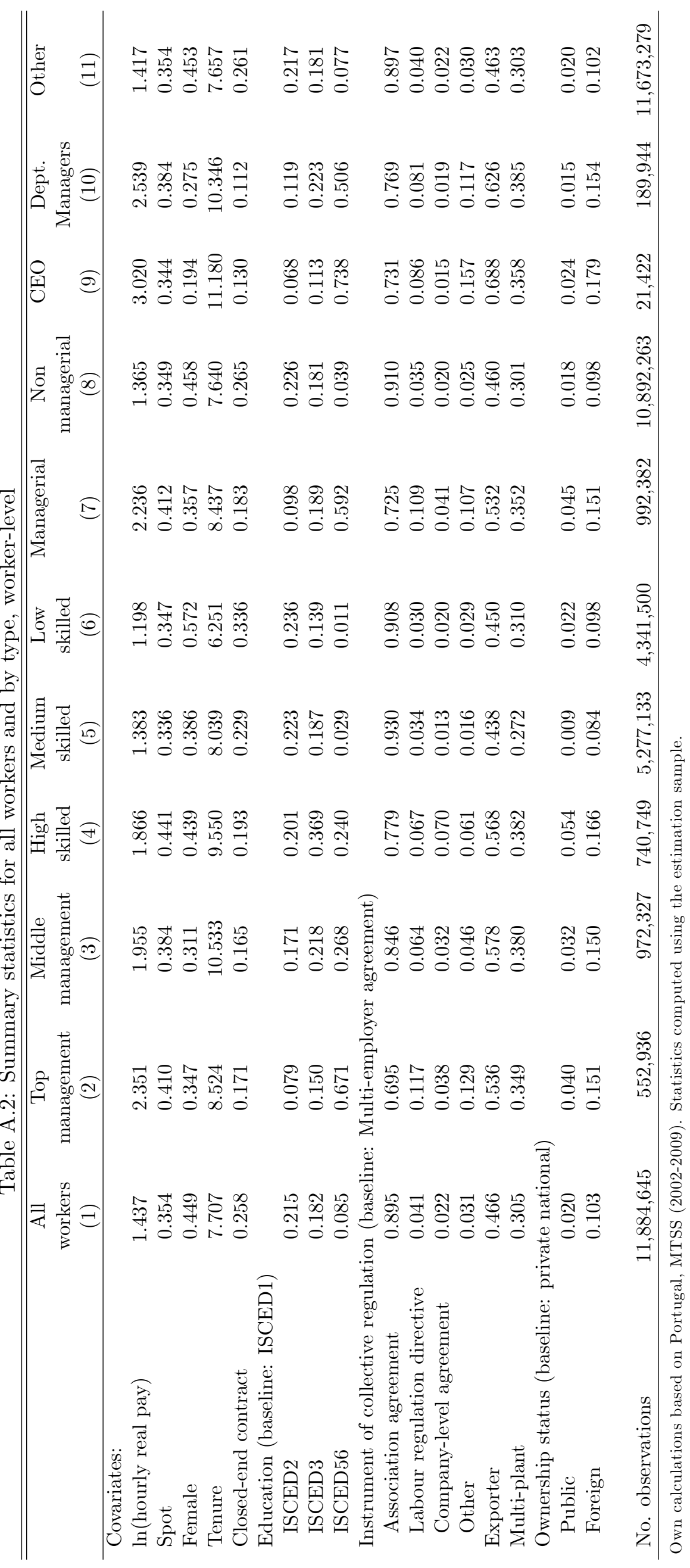


Table A.3: Summary statistics of firm- and municipality-level variables

\begin{tabular}{lccc}
\hline \hline & Mean & Std.dev. & No. Obs. \\
\hline Firm Size (all firms) & & & \\
Share of females in workforce (all firms) & 0.677 & 72.930 & $1,428,151$ \\
Share of low skilled workers (all firms) & 0.461 & 0.417 & $1,428,151$ \\
Firm Size (incumbents) & 0.349 & 0.380 & $1,428,151$ \\
Firm Size (new entrant firms) & 9.691 & 75.330 & $1,746,522$ \\
Femshare $t-1$ (all firms) & 4.002 & 15.974 & 135,218 \\
Femshare $_{\text {pre-spot }}$ (all firms) & 0.456 & 0.412 & $1,081,868$ \\
Femsharet-1 (excluding small firms) & 0.467 & 0.402 & 647,249 \\
Femshare pre-spot (excluding small firms) & 0.394 & 0.336 & 306,506 \\
Female share growth & 0.406 & 0.331 & 205,743 \\
All workers & & & \\
Managerial & 0.013 & 1.393 & $1,081,868$ \\
High-skilled & 0.034 & 1.679 & 187,699 \\
Medium-skilled & 0.048 & 1.673 & 326,843 \\
Low-skilled & 0.007 & 1.518 & 726,505 \\
Number of new entrant firms (municipality-industry) & -0.002 & 1.422 & 574,422 \\
New firms/incumbents (municipality-industry) & 2.406 & 8.272 & 56,782 \\
Characteristics of new firms in treatment municipalities & 0.073 & 0.177 & 55,784 \\
Size & & & \\
ln(real sales) & 3.917 & 15.747 & 47,716 \\
Survival rate after 2 years & 10.338 & 1.210 & 8,425 \\
Characteristics of new firms in non-treatment municipalities & 0.779 & & \\
Size & 4.048 & 16.096 & 87,502 \\
ln(real sales) & 10.411 & 1.191 & 15,733 \\
Survival rate after 2 years & 0.751 & & \\
\hline
\end{tabular}

Own calculations based on Portugal, MTSS (2002-2009). Statistics computed using the estimation samples. Survival rates were estimated for firms created in or after 2005. We allowed for a one-year window of observation to identify firm closures. We have tested whether the observed differences in the survivor functions for municipalities with and without one-stop shops are statistically significant and rejected the null hypothesis of no subgroup differences in survivor functions. 
Table A.4: Effect of the "On the Spot Firm" program on firm entry, negative binomial estimates

\begin{tabular}{|c|c|c|}
\hline \multirow[t]{2}{*}{ Dependent variable: } & \multicolumn{2}{|c|}{ New firms } \\
\hline & $(2)$ & (3) \\
\hline Stop & $\begin{array}{c}0.075^{* * *} \\
(0.019)\end{array}$ & $\begin{array}{c}0.079^{* * *} \\
(0.020)\end{array}$ \\
\hline $\mathrm{ME}$ & $\begin{array}{c}0.182^{* * *} \\
(0.046)\end{array}$ & $\begin{array}{c}0.196^{* * *} \\
(0.050)\end{array}$ \\
\hline Constant & $\begin{array}{c}0.590^{* * *} \\
(0.017)\end{array}$ & $\begin{array}{c}0.287^{* * *} \\
(0.047)\end{array}$ \\
\hline Municipality FE & Yes & Yes \\
\hline Industry FE & & Yes \\
\hline Year FE & Yes & Yes \\
\hline $\mathrm{R}^{2}$ & 0.061 & 0.291 \\
\hline No. Obs. & 56,782 & 56,782 \\
\hline $\begin{array}{l}\text { The dependent variable } \\
\text { firms. Observations are by } \\
\text { These results come from ne } \\
\text { ME stands for marginal ef } \\
\text { rors, clustered by municip } \\
\text { theses. }{ }^{*} \mathrm{p}<0.10,{ }^{* *} \mathrm{p}<0 \text {. }\end{array}$ & $\begin{array}{l}\text { is the num } \\
\text { municipality-it } \\
\text { gative binomis } \\
\text { fects. Robust } \\
\text { lity are repor } \\
5,{ }^{* * *} \mathrm{p}<0.01\end{array}$ & $\begin{array}{l}\text { ber of new } \\
\text { ldustry-year. } \\
\text { l estimation. } \\
\text { standard er- } \\
\text { ted in paren- } \\
\end{array}$ \\
\hline
\end{tabular}


Table A.5: Effect of the "On the Spot Firm" program on the gender pay gap, by gender

\begin{tabular}{|c|c|c|c|c|c|c|}
\hline \multirow[t]{3}{*}{ Dependent variable: } & \multicolumn{6}{|c|}{ ln Compensation } \\
\hline & \multicolumn{2}{|c|}{ Skill levels } & \multicolumn{2}{|c|}{ Managerial } & \multicolumn{2}{|c|}{ Occupation } \\
\hline & $\begin{array}{l}\text { Male } \\
(1)\end{array}$ & $\begin{array}{c}\text { Female } \\
(2)\end{array}$ & $\begin{array}{c}\text { Male } \\
(3)\end{array}$ & $\begin{array}{l}\text { Female } \\
(4)\end{array}$ & $\begin{array}{l}\text { Male } \\
(5)\end{array}$ & $\begin{array}{c}\text { Female } \\
(6)\end{array}$ \\
\hline Med-skill $\times S t o p$ & $\begin{array}{l}-0.001 \\
(0.004)\end{array}$ & $\begin{array}{c}0.010^{* * *} \\
(0.003)\end{array}$ & & & & \\
\hline High-skill $\times$ Stop & $\begin{array}{c}0.013^{* * *} \\
(0.003)\end{array}$ & $\begin{array}{c}0.030^{* * *} \\
(0.006)\end{array}$ & & & & \\
\hline Mid-manag $\times S t o p$ & $\begin{array}{c}0.022^{* * *} \\
(0.004)\end{array}$ & $\begin{array}{c}0.038^{* * *} \\
(0.004)\end{array}$ & & & & \\
\hline Top-manag $\times S t o p$ & $\begin{array}{c}0.033^{* * *} \\
(0.005)\end{array}$ & $\begin{array}{c}0.038^{* * *} \\
(0.003)\end{array}$ & & & & \\
\hline Manager $\times$ Stop & & & $\begin{array}{c}0.030^{* * *} \\
(0.004)\end{array}$ & $\begin{array}{c}0.036^{* * *} \\
(0.003)\end{array}$ & & \\
\hline Dept-Manag $\times S t o p$ & & & & & $\begin{array}{c}0.037^{* * *} \\
(0.005)\end{array}$ & $\begin{array}{c}0.048^{* * *} \\
(0.006)\end{array}$ \\
\hline $\mathrm{CEO} \times$ Stop & & & & & $\begin{array}{c}0.038^{* * *} \\
(0.005)\end{array}$ & $\begin{array}{c}0.043^{* * *} \\
(0.010)\end{array}$ \\
\hline Stop & $\begin{array}{l}-0.002 \\
(0.004)\end{array}$ & $\begin{array}{c}-0.008^{* * *} \\
(0.002)\end{array}$ & $\begin{array}{l}-0.000 \\
(0.002)\end{array}$ & $\begin{array}{l}-0.001 \\
(0.002)\end{array}$ & $\begin{array}{c}0.002 \\
(0.002)\end{array}$ & $\begin{array}{c}0.001 \\
(0.002)\end{array}$ \\
\hline Med-skill & $\begin{array}{c}0.025^{* * *} \\
(0.002)\end{array}$ & $\begin{array}{c}0.013^{* * *} \\
(0.002)\end{array}$ & $\begin{array}{c}0.024^{* * *} \\
(0.001)\end{array}$ & $\begin{array}{c}0.016^{* * *} \\
(0.003)\end{array}$ & $\begin{array}{c}0.024^{* * *} \\
(0.001)\end{array}$ & $\begin{array}{c}0.016^{* * *} \\
(0.003)\end{array}$ \\
\hline High-skill & $\begin{array}{c}0.036^{* * *} \\
(0.002)\end{array}$ & $\begin{array}{c}0.027^{* * *} \\
(0.003)\end{array}$ & $\begin{array}{c}0.041^{* * *} \\
(0.002)\end{array}$ & $\begin{array}{c}0.041^{* * *} \\
(0.002)\end{array}$ & $\begin{array}{c}0.040^{* * *} \\
(0.002)\end{array}$ & $\begin{array}{c}0.040^{* * *} \\
(0.002)\end{array}$ \\
\hline Mid-manag & $\begin{array}{c}0.061^{* * *} \\
(0.003)\end{array}$ & $\begin{array}{c}0.065^{* * *} \\
(0.003)\end{array}$ & $\begin{array}{c}0.068^{* * * *} \\
(0.003)\end{array}$ & $\begin{array}{c}0.080^{\text {*** }} \\
(0.009)\end{array}$ & $\begin{array}{c}0.067^{* * *} \\
(0.002)\end{array}$ & $\begin{array}{c}0.078^{* * *} \\
(0.006)\end{array}$ \\
\hline Top-manag & $\begin{array}{c}0.064^{* * *} \\
(0.003)\end{array}$ & $\begin{array}{c}0.065^{* * *} \\
(0.003)\end{array}$ & $\begin{array}{c}0.072^{* * *} \\
(0.003)\end{array}$ & $\begin{array}{c}0.079^{* * *} \\
(0.007)\end{array}$ & $\begin{array}{c}0.066^{* * *} \\
(0.003)\end{array}$ & $\begin{array}{c}0.074^{* * *} \\
(0.004)\end{array}$ \\
\hline Manager & & & $\begin{array}{c}-0.007^{* *} \\
(0.003)\end{array}$ & $\begin{array}{l}-0.013 \\
(0.009)\end{array}$ & & \\
\hline Dept-Manag & & & & & $\begin{array}{c}0.043^{* * *} \\
(0.003)\end{array}$ & $\begin{array}{c}0.033^{* * *} \\
(0.006)\end{array}$ \\
\hline $\mathrm{CEO}$ & & & & & $\begin{array}{c}0.069^{* * *} \\
(0.007)\end{array}$ & $\begin{array}{c}0.045^{* * *} \\
(0.012)\end{array}$ \\
\hline Promotions & $\begin{array}{c}0.036^{* * *} \\
(0.002)\end{array}$ & $\begin{array}{c}0.029^{* * *} \\
(0.002)\end{array}$ & $\begin{array}{c}0.037^{* * *} \\
(0.002)\end{array}$ & $\begin{array}{c}0.030^{* * *} \\
(0.002)\end{array}$ & $\begin{array}{c}0.037^{* * *} \\
(0.002)\end{array}$ & $\begin{array}{c}0.030^{* * *} \\
(0.002)\end{array}$ \\
\hline Year FE & Yes & Yes & Yes & Yes & Yes & Yes \\
\hline Match (worker-firm) FE & Yes & Yes & Yes & Yes & Yes & Yes \\
\hline $\mathrm{R}^{2}$ & 0.086 & 0.093 & 0.086 & 0.092 & 0.086 & 0.092 \\
\hline No. Obs. & $6,545,601$ & $5,339,044$ & $6,545,601$ & $5,339,044$ & $6,545,601$ & $5,339,044$ \\
\hline
\end{tabular}

The dependent variable is the natural $\log$ of real hourly pay. Skill categories are defined in Section 3.1. Other covariates include the workers' tenure and its square, the level of education, the type of employment contract (whether open-ended or fixed-term), the instrument of collective regulation, the natural log of firm size (number of employees), the share of females in the workforce, the share of low skilled workers in total firm employment, whether the firm is an exporter, whether it is multi-establishment, and ownership type. Robust standard errors, clustered by municipality, are reported in parentheses. ${ }^{*} \mathrm{p}<0.10{ }^{* *} \mathrm{p}<0.05{ }^{* * *} \mathrm{p}<0.01$. 